\title{
Dezavantajlılık bağlamında proje yaklaşımı: Öğretmenler, çocuklar ve ailelerin deneyimleri ${ }^{1}$
}

\author{
The project approach in disadvantaged contexts: Describing the \\ experiences of teachers, children and families ${ }^{2}$
}

\begin{abstract}
Makale Geçmişi
Geliş : 13 Ocak 2020

Düzeltme : 5 Mart 2020

Kabul : 6 Mart 2020
\end{abstract}

\section{Makale Türü}

Araștirma Makalesi

\section{Article History \\ Received : 13 January 2020 \\ Revised : 5 March 2020 \\ Accepted : 6 March 2020}

\section{Article Type}

Research Article

\author{
Arzu ARIKAN ${ }^{3}$
}

Öz: Bu araştırmanın amacı dezavantajlılık bağlamında okul öncesi öğretmenleri, çocuklar ve ailelerin proje yaklaşımı konusundaki deneyimlerini betimlemektir. Nitel araştırma yöntemlerinden eylem araştırması ve durum çalışması sentezinde özgün bir desenle yürütülen bu çalışmada amaçlı örnekleme yöntemine başvurulmuştur. Araştırmanın katılımcıları dezavantajlı gruplara hizmet eden bir anaokuluna kayıtlı 3-6 yaş grubundaki çocuklar, aileleri ve okul personelidir. Araştırmada proje yaklaşımı eylem planı olarak uygulanmıştır. Veri toplamada gözlem, yarı-yapılandırılmış görüşme, araştırmacı günlükleri ve çeşitli kurumsal belgelere başvurulmuştur. Bu araştırma kapsamında elde edilen zengin veri setinden proje uygulamalarına yönelik olanlar kullanılmıştır. Veri analizinde, ATLAS.ti 7 yazılımı kullanılmıştır. Bulgular, proje uygulamalarının mesleki gelişimi desteklediğini göstermektedir. Ancak, öğretmenler bu kazanımlarını eğitime kısmi uygulamalar şeklinde yansıtmışlardır ve proje yaklaşımını, zorluklarından dolayı dönem içinde uygulamaya direnç göstermişlerdir. Dezavantajlı çocuklar proje sürecinde öğretmenlerin beklentilerini aşmış ve sosyal-duygusal, bilişsel ve dil alanında kazanımlar sergilemişlerdir. Ailelerin eğitsel farkındalığı ve çocuklarla etkileşimleri artmıştır. Sonuç olarak, proje yaklaşımında öğretmenler için zaman kaybı ve iş yükünü azaltacak değişiklikler yapılması, kaynaklar sunulması, işbaşında hizmet içi eğitim yaklaşımlarına başvurulması ve öğretmenlerin desteklenmesi proje uygulamalarında onları güdüleyebilir.

Anahtar Kelimeler: Okul Öncesi Eğitim, Düşük Gelirli Aileler; Aile Katılımı, Yoksulluk, Eylem Araştırması, Durum Çalışması, Bilim Eğitimi

\begin{abstract}
The purpose of this qualitative study is to describe the experiences of preschool children, families, and teachers related to the project approach implementation in the context of disadvantaged conditions. The research design included a synthesis of a case study and action research. Using purposeful sampling methods, the participants included 3-6-year-old children, their families, and the staff in a preschool, serving disadvantaged children. The action plan included the implementation of the project approach. Multiple data collection techniques included the use of semi-structured interviews, observations, the researcher journals, and obtaining various documents. This research uses data relevant to project implementation from a comprehensive data set collected over a year. Data analysis employed inductive methods using ATLAS.ti 7 software. Findings show that the project approach supported the teachers' professional development. The teachers have partially adopted some educational practices they have learned during the project implementation. However, they were resistant to implement the project approach as a whole during the academic year. Disadvantaged children exceeded the expectations of the teachers and exhibited social-emotional, cognitive, and language gains during the project. Families also increased their educational awareness and quality interactions with their children. Changing some implementation features to reduce time and workload for teachers, offering resources, using on-site approaches for in-service training, supporting teachers may motivate them to implement the project approach.
\end{abstract}

Keywords: Preschool Education, Low-income Families, Parent Involvement, Poverty, Action Research, Case Study, Science Education

DOI: $10.24130 /$ eccd-jecs.1967202041215

\footnotetext{
${ }^{1}$ Bu araştırma Anadolu Üniversitesi Bilimsel Araştırma Projeleri Komisyonu tarafından kabul edilen 1406 E307 nolu proje kapsamında desteklenmiştir.

${ }^{2}$ Bu çalışmanın erken örnekleri Ankara'da yapılan II. Uluslararası Avrasya Eğitim Araştırmaları Kongresinde ve Çanakkale'de yapılan VII.

Uluslararası Eğitimde Araştırmalar Kongresinde sözlü bildiri olarak sunulmuştur.

Başlica Yazar:

${ }_{3}^{3}$ Anadolu Üniversitesi, Eğitim Fakültesi, Temel Eğitim Bölümü, arzuarikan@anadolu.edu.tr, ORCID: https://orcid.org/0000-0002-4602-8901
} 


\section{SUMMARY}

\section{Introduction}

Although various factors influence the development and learning of children living in disadvantaged conditions, preschool education plays an essential role in reducing the effects of adverse environments. Multiple studies with children from low-income groups also show that early education is critical for school readiness, and it supports young children's development and learning. However, educational intervention at a young age is not sufficient alone. High-quality educational experiences are necessary for the sustainability of these effects. In this respect, education programs based on problem-solving and providing real experiences are contemporary building blocks for quality education. The project approach offers rich learning experiences and inquiry-based activities for children. The increasing number of implementation examples and empirical studies also show that the project approach supports the development of children of different ages. However, the research examining the project approach with multiple participants in diverse school settings are scarce. Investigating the project implementation in socioeconomically disadvantaged contexts may shed light on the dynamics of the project approach with different groups of children. The purpose of this qualitative study is to describe the project experiences of preschool teachers, children, and families in disadvantaged contexts.

\section{Method}

The research design included a synthesis of a case study and action research. The research participants were determined by purposeful sampling. The project approach was implemented as the action plan to solve the issues reported by the teachers in the school. Due to the changing attitudes of the teachers during the research process, the researcher hired a substitute teacher and took a more active role in the project implementation. Happy Ants Kindergarten, serving disadvantaged children aged 3-4 years old and 5-6 years old, was the research setting. The preschool teachers and other school staff, children enrolled in the school, and their families participated in the study. For data collection, audio-visual recordings, researcher journals, and field notes were kept; observation and semi-structured interviews were conducted, and various documents were collected. Carrying out the action plan took place in three stages that included preparation, implementation, and monitoring. The project approach was implemented during the summer session in the preschool. The data were analyzed using the inductive and constant comparison approach in ATLAS.ti 7 software. Triangulation of the data sources, systematic data analysis, keeping researcher journals, and prolonged engagement in the field ensured the trustworthiness of the study.

\section{Results}

The findings show that preschool teachers have partially adopted some educational practices they have learned during the project implementation. However, they were resistant to implement the project approach as a whole during the academic school year. The professional development of preschool teachers was supported, but there were significant difficulties related to the project implementation for teachers. They 
suggested implementing the project approach during the summer sessions when they did not use prescribed educational plans. Teachers noted some difficulties regarding the project approach. Some of these difficulties included integrating the project approach with prescribed plans, extra time needed for the projects, the increased workload, and the high number of children attending school during the academic year. They emphasized the difficulty of teaching on a full day and full-year basis. There were also negative relationships among school staff that may predict teachers' attitudes towards project implementation. As for the children, they were active in the project activities, exceeded the expectations of the teachers, and showed progress in social-emotional, cognitive, and language domains. However, the children who benefited from the project implementation the most were those who regularly attended the school. The parents' educational awareness and their interaction with children also increased during the project implementation. Families made an effort to respond to school inquiries and had the opportunity to talk and learn from their children via their increased interactions.

\section{Conclusion and Discussion}

The results of this research are similar to the literature related to the project approach. While it supports learning and growth for all involved parties, there are multiple difficulties for teachers. This trend suggests that changing some features of the project approach in order to decrease time and workload may increase motivation for teachers who work all day and year-round. In order to achieve this, online resources and time for planning may be offered for teachers. Based on teachers' partial adoption of some practices that they observed during the project process, in-service training sessions on-site may be useful. The school climate also appears to affect educational practices. In light of present circumstances, the sustainability of the project implementation in the long term appears to be vague. Teachers appear to need support in working with disadvantaged children and families. Continuous in-service training for teachers about working with disadvantaged groups may help them gain an inclusive perspective. Finally, this study has two limitations that may obscure the transferability of the results. All teachers participating in the study were women, and a substitute teacher implemented the project under the guidance of the researcher. Future research may expand the investigation by involving male teachers as participants and by conducting participatory action research with teachers who are determined to implement the project approach in their classroom. 


\section{GİRİŞ}

Türkiye'de çocuklar eğitim sistemine ilk adımlarını okul öncesi eğitimle atmakta ancak hepsi bu fırsattan yeterince faydalanamamaktadır. Özellikle sosyoekonomik açıdan dezavantajlı koşullarda yaşayan çocuklar için bu durum önemli bir sorun teşkil etmektedir. Zira bu koşullar hem aileler hem de çocuklar için pek çok diğer olumsuzluğu da beraberinde getirmektedir. Dezavantajlı çocuklar, daha avantajlı koşullarda yaşayan yaşıtlarından gelişimsel ve akademik açıdan geride kalmaktadır. Bu gruplarla yapılan bilimsel çalışmalar da çocuklarda yaygın olarak sosyal-duygusal sorunlara, akademik başarının düşüklügüne ve ailelerinin eğitime katılımında sınırlllıklara işaret etmektedir (Chang, Park, Singh ve Sung, 2009; Crosnoe ve Cooper, 2010; Miller, Maguire ve Macdonald, 2012).

Dezavantajlı koşullarda yaşayan çocukların gelişim ve öğrenmesinde çeşitli faktörler etkili olmakla birlikte olumsuz koşulların etkilerini azaltmada okul öncesi eğitim önemli bir rol oynamaktadır. Crosnoe ve diğerleri (2010), dezavantajlı koşullarda yaşayan çocuklar için erken yaşlarda uyarıcı eğitim ortamları ve zengin öğrenme deneyimleri sunulmasının önemli farklar yarattığına işaret etmektedir. Düşük gelir gruplarından çocuklarla yapılmış çeşitli çalısmalar da erken çocukluk eğitiminin gelişim ve öğrenmeyi desteklediğini ve ilkokula hazırladığını göstermektedir (Borre, Bernhard, Bleiker ve Winsler, 2019; Winsler ve diğerleri, 2008). Ancak, erken yaşlardan itibaren eğitimle müdahale tek başına yeterli olmayıp beklenen etkilerin sürdürülebilirliği için eğitimde nitelik de gerekli koşullardan biridir (Dearing, McCartney ve Taylor, 2009). Bu açıdan, çağdaş uygulamalar içeren, somut yaşantılar sunan ve problem çözmeye dayalı eğitim programları nitelikli eğitimin yapı taşlarıdır. Bu araştırma kapsamında da araştırma ve sorgulama temelli çalışmalar içeren proje yaklaşımı dezavantajlılık bağlamında incelenmiş olup okul öncesi öğretmenleri, çocuklar ve ailelerin uygulama sürecindeki deneyimleri betimlenmiştir.

Proje yaklaşımı farklı eğitim kademelerinde proje yöntemi, proje-temelli eğitim ve proje-tabanlı eğitim şeklinde adlandırılmaktadır. Bu çalışmada okul öncesi eğitim kademesinde daha sık kullanılan proje yaklaşımı kavramı tercih edilmiştir. Proje yaklaşımı, çocukların gündelik yaşamından bir konunun derinlemesine araştırıldığı esnek bir eğitim yaklaşımı şeklinde tanımlanmakta; çocuğu, öğretmeni, aileyi ve çevreyi etkin kılmaktadır (Helm ve Katz, 2001; Katz ve Chard, 2000). Proje çalışmaları kapsamında somut yaşantılar ve farklı temsil firsatları içeren etkinlikler aşamalar halinde gerçekleştirilir. Deneysel öğrenme, araştırmaya dayalı öğrenme, probleme dayalı öğrenme gibi birçok tekniğe başvurulan bu çocuk merkezli yaklaşımda, çocuklar etkin öğrenen rolündedir. Öğretmen rehberliğinde yapılan saha çalışmaları ve uzmanlarla etkileşimin de önemli olduğu proje 
çalışmaları ile çocuklar ilgi duydukları bir konuda ve gerçek yaşamda karşılaştıkları nesne ya da durumlara yönelik araştırma ve değerlendirme yapma fırsatı bulurlar. Araştırılan konu öğrenme için bir araç işlevi görür ve yapılan çalışmalar bu yaklaşımın süreç odağını yansıtacak nitelikte öğretmen tarafindan belgelenir. Dokümantasyon olarak da bilinen bu belgeleme sınıfta bir pano veya duvarda sergilenerek çocuklar ve öğretmen kendilerini değerlendirirler (Dahlberg ve Moss, 2010; Miller, 2014).

Proje yaklaşımının çeşitli özellikleri değerlendirildiğinde günlük hayatlarında yetersiz uyaranlarla karşılaşan dezavantajlı çocuklar için nitelikli bir eğitim zemini oluşturabileceği anlaşılmaktadır. Alanyazına yansıyan uygulama örnekleri ve araştırmalar da proje yaklaşımının farklı eğitim kademelerinde çocukların etkin katılımını sağladığını ve gelişimlerini çok yönlü desteklediğini göstermektedir (Holm, 2011). Proje çalışmalarının çocuklar için etkileri, öğrenmenin kalıcı olması, akademik başarının artması, bilişsel becerilerin desteklenmesi, dil gelişimine yönelik kazanımlar, zihinsel eğilimler ve duygusal katılımın güçlenmesi ve okula hazırlık şeklinde özetlenebilir (Brooks ve Wangmo, 2011; Carida, 2011; Clucas, 2018; Sawyer, 2013). Öğretmenler ve ailelerle yapılan araştırmalar da proje yaklaşımının olumlu etkilerine ve mesleki gelişimi desteklediğine dair bulgular içermektedir (Beneke ve Ostrosky, 2009; Yuen, 2009). Proje yaklaşımına yönelik ilgi yerel ölçekte de oldukça yüksek olup uygulamalara rehberlik eden pek çok çalışma bulunmaktadır (Çabuk ve Haktanır, 2010; Kandır ve Kurt, 2010; İnan, 2012; Metin ve Aral, 2014; Oğuz, Gizir ve Akyol, 2014; Öztürk, 2019). Ancak bilimsel açıdan uluslararası alan yazına göre daha sınırlı sayıda araştırma olup özellikle okul öncesi kademesinde belirli gelişim alanlarına odaklanan deneysel çalş̧malar ağırlıktadır (Aral ve diğerleri, 2010; Bıçakçı ve Gürsoy, 2010; Şahin, Güven ve Yurdatapan, 2011). Az sayıda araştırmada ise proje yaklaşımı nitel yaklaşımlarla değerlendirilmiştir (Baysura, Altun ve Yücel-Toy, 2016; Kabacık ve Gül, 2016; Kefi, 2017). Proje yaklaşımının çocuklar üzerindeki etkileri açısından Türkiye'de yapılan araştırmalar uluslararası alan yazınla paralel bulgular içermektedir.

Farklı ülkelerde yapılan bilimsel araştırmalar değerlendirildiğinde proje yaklaşımının daha çok tek bir gruba odaklı araştırıldığı görülmektedir. Bu konuda çocuklar dışındaki katılımcıları içeren çalışmalar ise sınırlı sayıdadır. Proje uygulamasına dâhil olan tüm katılımcıların deneyimlerinin araştırılması çok boyutlu bir değerlendirme yapılabilmesine imkân sağlayacaktır. Sosyoekonomik veya kültürel açıdan farklı grupların deneyimlerine 1şık tutan araştırmalar da az sayıda olup kaynaştırma sınıflarında ve etnik çeşitlilik içeren okullarda yapılan birkaç araştırmaya ulaşılabilmiştir (Beneke, 2010; Hovey ve Ferguson, 2014). Bu kapsamda, alan yazın dezavantajlı çocuklarla proje yaklaşımının uygulanması konusunda da boşluklara işaret etmektedir. Proje yaklaşımının çok yönlü olarak ve sosyoekonomik bağlamda daha iyi anlaşılması ihtiyacından hareketle bu araştırmanın 
temel amacı dezavantajlılık bağlamında okul öncesi öğretmenleri, çocuklar ve ailelerin deneyimlerini betimlemektir. Çalışma için dezavantajlı gruplara hizmet veren bir anaokulunda proje yaklaşımı uygulanmış ve öğretmenler, çocuklar ve ailelerin proje deneyimleri çok yönlü olarak araştırılmıştır.

\section{YÖNTEM}

Bu araştırma nitel yöntemlerden eylem araştırması ve durum çalışması sentezinde özgün bir desenle gerçekleştirilmiştir. Araştırmanın başlangıcında eğitimciler hem çocuklarda gözledikleri davranış sorunlarına işaret etmişler hem de aile katılımının düşüklügünden yakınmışlardır. Bu sorunları çözmek için eylem araştırması kapsamında proje yaklaşımının uygulanmasına eğitimcilerle beraber karar verilmiştir. Araştırma sürecinin başında güdülenmiş görünen öğretmenlerin katılım ve işbirliği düzeyleri araştırma başlayınca düşmüştür. Bu yüzden, araştırmacı daha etkin bir rol almıss ve yüksek lisans eğitimine devam eden ücretli bir öğretmenden proje uygulamasında destek alarak araştırmayı sürdürmüştür. Böylece, bu araştırma süreç başladıktan sonra eylem araştırması ve durum çalışmasını sentezleyen bir desende tamamlanmıştır (Creswell, 2007; Mac Naughton ve Hughes 2009; Merriam, 2009).

\section{Kat1limc1lar}

Araştırma sahası ve katılımcılar amaçlı örnekleme yöntemi ile belirlenmiştir. Araştırma için dezavantajlı koşullarda yaşayan çocuklara ücretsiz hizmet veren Mutlu Karıncalar Anaokuluna ulaşılmıştır. Bu okul İç Anadolu bölgesinde orta büyüklükteki bir il merkezinde olup MEB dışında bir kuruma bağlı olarak işletilmektedir. Okulda 3-4 yaş (küçük yaş) ve 5-6 yaş (büyük yaş) grubu olmak üzere iki sınıf bulunmakta ve ihtiyaç sahibi ailelerin çocuklarına tam gün ve yaz ayları dâhil tüm yıl eğitim hizmeti verilmektedir. Okul şubat, haziran ve eylül aylarında ikişer hafta tatile girmektedir. Aileler, düşük gelire sahip olup hizmet sektöründe güvencesiz işlerde çalışmakta veya işsizdir. Ailelerin çoğunluğu boşanma, ölüm, terk veya eşin cezaevinde olması gibi sebeplerden dolayı tek ebeveynli yapıdadır. Bu ailelerin çoğunluğu da kadın ve çocuklardan oluşmaktadır.

Araştırmanın başladığı dönemde okula kayıtlı toplam 42 çocuk, her sınıfta ise en fazla 22 çocuk vardır. Kuruma yazın devam etme ailelerin isteğine bırakılmakta ve yaz aylarında sınıf mevcudu düşmektedir. Kurumda tamamı çocuk gelişimi veya okul öncesi öğretmenliği mezunu olan dört öğretmen, bir okul müdürü ve bir sekreter çalışmaktadır. Her sınıfta iki öğretmen görev yapmakta; öğretmenler raporlu veya izinli olduğunda sekreter de sinıflarda öğretmenlik rolü üstlenmektedir. Okul müdürü de öğretmenler arasından seçilmiştir. Bu nedenle öğretmen, müdür ve sekreter gibi sınıfa giren tüm grup için eğitimciler ifadesi kullanılmıştır. Okulda iki tane temizlik, iki tane de 
mutfak işlerinden sorumlu dört destek personeli çalışmaktadır. Okul çalışanların tamamı kadındır. Anaokulunda çalışan eğitimciler, 3 destek personeli, okula kayıtlı 3-6 yaş grubundaki çocuklar ve aileleri bu çalışmanın katılımcıları olmakla birlikte projeye yönelik son değerlendirme görüşmeleri sadece yazın uygulamaya dâhil olan aile ve çocuklarla yapılmıştır. Okulda bazı aileler izin aldıklarından, bazıları da dönem sonunda kayıtlarını sildirdiklerinden dolayı proje uygulanan yaz döneminde ortalama 25 çocuk okula devam etmiştir. Büyük yaş sınıfinda görev alan ücretli ögretmen de araştırmanın katılımcısı olmuştur.

\section{Veri Toplama}

Bu araştırmada, 2014 İlkbahar döneminden 2015 Yaz dönemi sonuna uzanan bir süreç boyunca gözlem ve görüşmeler yapılmış, proje yaklaşımı uygulanmış ve çeşitli kurumsal belgeler toplanmıştır. Veri toplama, proje uygulamadan önce ve sonra edinilen bilgi ve belgelerle birlikte bir yılı aşkın bir süreçte tamamlanmış ve farklı veri toplama tekniklerine başvurulmuştur. Bunlar, gözlem, yarı-yapılandırılmıss görüşmeler ve çeşitli belgelerin toplanmasıdır. Veri toplama sırasında görsel-işitsel kayıtlar yapılmış, araştırmacı günlükleri ve saha notları tutulmuştur. Araştırmanın başlangıcında 3 öğrenci de ilk tur gözlemlerde ve öğretmenlerle yapılan ilk görüşmelerde görev almıştır'. Farklı katılımcılardan elde edilen veriler Tablo 1'de gösterilmiştir.

Tablo 1. Katılımc1lardan elde edilen veriler

\begin{tabular}{|c|c|c|c|c|}
\hline Katılımcı Grubu & $\begin{array}{l}\text { Küçük } \\
\text { Yaş }\end{array}$ & Büyük Yaş & Veri Kaynağ1 & $\begin{array}{c}\text { Toplam } \\
\text { Görüşme } \\
\text { Sayısı }\end{array}$ \\
\hline Sınıf Öğretmeni & 2 & 2 & $\begin{array}{l}\text { Görüşme, gözlem, günlük akışlar, toplantı } \\
\text { kayıtları }\end{array}$ & 16 \\
\hline Çocuk & 17 & 18 & $\begin{array}{l}\text { Görüşme, gözlem, yoklama listeleri, gelişim } \\
\text { raporları, çocukların ürünleri, tanıtım } \\
\text { dosyaları, fotoğraflar }\end{array}$ & 41 \\
\hline Aileler $^{2}$ & 17 & 17 & Görüşme & 54 \\
\hline Ücretli Öğretmen & - & 1 & Görüşme-gözlem & 1 \\
\hline Destek Personeli & & 3 & Görüşme & 5 \\
\hline Müdür \& Sekreter & & 2 & Görüşme, idari belgeler & 8 \\
\hline
\end{tabular}

Araştırmanın başında haftanın farklı günlerini örnekleyecek şekilde gerçekleştirilen gözlemler uygulama ve izleme aşamalarında okulun açık olduğu her gün görsel-işitsel araçlarla destekli olarak devam ettirilmiştir. Araştırma boyunca her grupla bir ila dört arası farklı sayıda yarı-yapılandırılmış görüșme yapılmıştır³. Görüşme süreleri yetişkinler için 20-120 dakika; çocuklar için 10-30 dakika

\footnotetext{
${ }^{1}$ Bu araştırmanın başlangıcında veri toplamaya yönelik katkılarından dolayı Ayça Engin Gökbel, Nurbanu Parpucu ve Vakkas Yalçın’a teşekkür ederim.

${ }^{2}$ Bir ailenin okula devam eden ikiz çocukları vardır. Proje değerlendirmesi için yapılan görüşmeler uvgulamaya katılan çocuklar ve aileleri ile sınırlandırılsa da belgelerin incelenmesinde diğer katılımcıların bilgilerinden de faydalanılmıștır.

${ }^{3}$ Metinde yapılan alıntılara kaynak olan görüşme numarası kısaltmalarla gösterilmiştir. Örneğin, (E1.G1) kısaltması, eğitimci 1 ile yapılan birinci görüşmeden alıntı yapıldığını göstermektedir. 
arasında değişmiştir. Görüşmeler sırasında ses kayıt cihazı kullanılmış ve görüşme protokolleri üzerine araştırmacı tarafindan notlar tutulmuştur. Ailelerle görüşmeye giderken çocuklara kalem, kâğıt, boya kalemleri, çalışma yaprakları, kitap gibi eğitim araçları götürülmüştür. Böylece görüşmelerin yapılabilmesi için evde sessiz bir ortam yaratılmıştır. Çocuklarla görüşmelerde dolgu bebek kullanımı, hikâye tamamlama, resim çizdirme gibi yöntemlere başvurulmuştur (Mac Naughton ve Hughes 2009).

Araştırma sürecinde okuldan kurumun işleyişi, eğitim süreci, çocuklar ve ailelerle ilgili yazılı belgeler toplanmış ve süreç boyunca çekilen fotoğraflar da belge olarak değerlendirilmiştir. Öğretmenlerden günlük eğitim akışları, çocukların gelişim raporları, yoklama listeleri ve çocukların etkinliklerde yaptıkları ürünlerden örnekler alınmıştır. Bu çalışmada görüşme ve gözlemler temel veri kaynağ1 olup diğer kurum belgeleri analizi destekleyici ikincil veri kaynağı olarak kullanılmıştır. Gözlem ve görüşmelerle zengin bir veri setine ulaşılmış olup bu çalışmada sadece proje uygulamalarını içerenler analiz edilmiştir.

\section{Eylem Planı}

Eylem planı hazırlık, uygulama ve izlemeden oluşan üç aşamayı ve bu aşamalara paralel yürütülen veri toplamayı içermiştir. Araştırmanın hazırlık aşamasında (Mart-Haziran, 2014) kurumdaki eğitimcilerden eylem araştırması kapsamında çözmek istedikleri sorunlar hakkında bilgi toplanmış ve okulda gözlemler yapılmıştır. Bu aşamada eğitimcilerin vurguladığı sorunlara çözüm olarak proje yaklaşımının eylem planı olarak uygulanmasına karar verilmiştir. Başlangıçta 6 saatlik proje yaklaşımı konulu bir eğitim planlanmışken, yapılan gözlemler ve okuldaki günlük etkinliklerin değerlendirilmesine dayalı olarak yeni ihtiyaçlar belirlenmiş ve öğretmenlere önce MEB 2013 Okul Öncesi Eğitim Programı konusunda bir eğitim, ardından da proje yaklaşımı ile ilgili eğitimler verilmiş ve eylem araştırması süreci açıklanmıştır.

Araştırmanın ikinci aşaması eylem planının uygulanmasını içermektedir. Eylem planı dâhilinde 2014 Yaz döneminde çocukların ilgi duyduğu konular belirlenerek proje yaklaşımı uygulanmıştır. Proje uygulamalarında Beneke (2010) tarafından geliştirilen kontrol listesindeki öğeler ve adımlara yer verilmiştir. Bu kapsamda büyük yaş grubu çocuklarla ağaçlar; küçük yaş grubunda ise ev hayvanları konulu projeler yürütülmüştür. Projenin uygulanması konusunda öğretmenlerin tereddütleri gözlendiğinden proje uygulamasının büyük yaş grubunda ücretli bir öğretmenle yürütülmesine karar verilmiş; sınıf öğretmeninden de uygulama günlerinde destek olması istenmiştir. Ağaçlar konulu 
proje, haftanın 3 günü 2014 Temmuz-Ağustos aylarında 30 okul gününde tamamlanmıştır ${ }^{1}$. Diğer günlerde ise sınıf öğretmenleri, ücretli öğretmenin yarım kalan bir etkinliğini, kendi planlarını veya araştırmacının önerdiği bazı proje etkinliklerini uygulamışlardır. Proje günlerinde ortalama beş farklı etkinlik uygulanmış; güne başlama ve günü değerlendirme zamanları da proje konusunda sohbet, bilmeceler, şarkı ve oyunlarla değerlendirilmiştir. Ağaçlar konulu projenin uygulandığı sınıfta etkinlikler video ve gözlemler yoluyla kayıt altına almıştır. Küçük yaş sınıfında ise öğretmenler ev hayvanları konulu projeyi kendi uygun gördükleri sıklıkta yürütmüş olup talep ettikleri zamanlarda kendilerine rehberlik edilmiştir. Bu sınıfta gözlem yapılmamış olmasına karşın proje çalışmaları sonucu ortaya çıkardıkları ürünler, günlük akışlar ve süreçle ilgili öğretmen ve aile görüşleri değerlendirilerek veri çeşitlemesi yapılmıştır.

Araştırmanın eylem planı uygulaması boyunca kurumda eğitim sürecine yansıyan olumsuz ilişkiler gözlendiğinden okul ikliminin dönüştürülmesine yönelik çalışmalar da yapılmış ve kurum çalışanları ile yansıtıcı grup toplantıları gerçekleştirilmiştir. Toplantılarda etkili iletişim, sağlıklı ilişkiler, nitelikli okulların özellikleri konularında eğitimler verilmiş ve çalışanlarla değerlendirme ve tartışmalar yapılmıştır. Bu aşamada farklı katılımcıların mevcut koşullardaki deneyimlerine yönelik de zengin veri elde edilmiş ancak bunlar çalışmanın kapsamını genişlettiğinden diğer çalışmalarda ayrıca değerlendirilmiştir².

Üçüncü aşamada (Eylül- Kasım, 2014) proje uygulamalarının kurumdaki yansımaları izlenmiştir. Proje yaklaşımı uygulandıktan sonraki dönemde okulda projenin yansımalarını izlemeye dönük video çekimleri yapılmış; fiziksel mekânların fotoğrafları çekilmiş, gözlemler öğretmenlerle paylaşılarak toplantılara devam edilmiş, görüşmeler yapılmış ve okulun sosyal ortamı gözlenmiştir. İzleme aşaması kasım ayı sonunda tamamlanmıştır. İzleme aşamasını takip eden aylarda kurumla ilişkiler devam etmiş olup, ağustos sonuna kadar gelişmeler izlenerek kuruma geri bildirim verilmiş ve işbirliğine devam edilmiştir. Öğretmenler, 2015 Yaz döneminde sınıflarında proje yaklaşımını uygulamışlar, araştırmacının yönlendirmesi ve rehberliği ile bu çalışmalarını bir konferansta sunmuşlardır. Bu aşamada fotoğraflarla okulun yıllık sergisi, sınıfların durumu ve proje sergisi kayıt altına alınarak bu fotoğraflar da veri kaynağı olarak değerlendirilmiştir.

\section{Veri Analizi}

\footnotetext{
${ }^{1}$ Ağaçlar konulu projenin uygulaması ve gerçekleştirilen etkinlikler yazarın "Okul Öncesi Ĕ̆itimde Proje Yaklaşımı: Ağaç Bilimcilerin Araştırmaları Projesi” adlı yayınında detaylı olarak açıklanmıştır.

2 Diğer çalışmalara örnek için bakınız Arıkan, 2017a. 
$\mathrm{Bu}$ araştırma kapsamında oluşturulan veri setinden proje uygulamalarına yönelik olanlar seçilerek analiz edilmiştir. Verilerin analizi sürecinde görüşmeler, gözlemler, belgeler ve videolar düzenlenerek analize uygun metinler haline getirilmiştir. Video kayıtlarından gözlemleri tamamlayıcı ölçüde faydalanılmıştır. İşlenen verilerin kodlanması ve düzenlenmesinde ATLAS.ti 7 yazılımı kullanılmıştır. Düzenlenen veriler sürekli karşılaştırma ve tümevarım yöntemi ile farklı döngülerde kodlanarak içerikleri analiz edilmiştir (Corbin ve Strauss, 2008; Friese, 2014; Miles, Huberman ve Saldaña, 2014; Saldaña, 2015). Analiz sürecinde kodların işaret ettiği ilişkiler, tema ve kategoriler altında düzenlenmiş, ulaşılan sonuçlar yorumlanmış ve veri bütünleştirilmiştir. Bulgular, farklı veri kaynakları ve katılımcılardan elde edilen bilgiler ile desteklenmiş, açıklamalarda negatif örneklere ve doğrudan alıntılara yer verilmiştir ${ }^{1}$. Veri kaynaklarının çeşitlendirilmesi, sistematik veri analizi, araştırmacı günlükleri ve sahada uzun zaman geçirme yoluyla araştırmanın geçerlik ve güvenirliği sağlanmıştır.

\section{Etik}

Araştırma için Üniversite Etik Kurulundan ve anaokulunun bağlı bulunduğu kamu kurumundan gerekli izinler alınmıştır. Katılımcılar, yapılacak uygulamalar ve araştırma konusunda hem yazılı hem de sözlü olarak bilgilendirilmiş; gönüllü katılım için sözlü ve yazılı onay alınmıştır. Çalışma ürünlerinde ve fotoğraflarda katılımcıların yüzleri ve isimleri gizlenmiş, takma isimler veya kodlar kullanılmıştır. Görüşmeler katılımcıların uygun gördüğü yer ve zamanlarda yapılmıştır. Gönüllü katılıma özen gösterilmiş ve öğretmenlerin projeyi uygulama konusunda değişen tutumları üzerine etik ilkelere uygun olarak araştırma deseni ve uygulama planı değiştirilmiştir. Çalışma sonunda kurumdaki tüm çocuklara hediye olarak kitap seti dağıtılmışır. Araştırmanın uygulama ve izlemesi tamamlandıktan sonra da öğretmenlere sonraki yaz döneminde uyguladıkları projeleri bir konferansta sunmaları için rehberlik edilmiştir.

\section{BULGULAR}

\section{Öğretmenlerin Deneyimleri: 'Proje içerisinden alacağımız çok şeyler var ama...'}

Araştırmanın başlangıcında Mutlu Karıncalar Anaokulunda yapılan gözlemler ve öğretmenlerin günlük planlarının incelenmesi sonucunda hazır planların kullanıldığı, sınırlı sayıda uyarıcı etkinliğe yer verildiği, çocukların sürekli aynı merkezlerde oynadığı, çizgi film izleme ve beslenme ve uyku rutinlerine fazlaca zaman ayrıldığı, etkinliklerin çoğunlukla sınıf içinde gerçekleştirildiği ve ailelerle iletişimde sınırlılıklar olduğu görülmüştür. Proje uygulamalan başlamadan önce dikkat çeken bu

\footnotetext{
${ }^{1}$ Katılımcıların gizliliğini korumak için görüşmelerde yapılan alıntılarda eğitimciler için E1, E2; Destek Personeli için DP1, DP2 şeklinde kodlar kullanılmıştır. 
bulgular konusunda öğretmenlerle grup toplantılarında değerlendirmeler yapılmış ve öğretmenlere çeşitli eğitimler verilmiştir. Uygulamada sınırlı çaba gösterseler de proje yaklaşımı öğretmenlerin mesleki gelişimini desteklemiş ve öğretmenler bu kazanımlarını eğitime kısmen yansıtmışlardır. Diğer taraftan, proje yaklaşımını zorluklarından dolayı dönem içinde bütün olarak uygulamaya direnç göstermişlerdir. Öğretmenlerin mesleki gelişime yönelik kazanımlarının eğitim sürecine kısmi yansımaları mikro uygulamalar kategorisinde değerlendirilmiştir.

Mikro Uygulamalar. Öğretmenler proje sürecinde öğrendikleri ve olumlu sonuçlarını gözledikleri bazı uygulamaları seçerek benimsemişlerdir. İzleme aşamasındaki gözlemler ve katılımcı görüşmeleri bu tezi destekleyen veriler sunmaktadır. Proje kazanımlanının kısmi yansımaları olarak değerlendirilen bu mikro uygulamalar; 1) genel yaklassım, 2) etkinlikeler, 3) ortam ve materyal kullanımı, 4) değerlendirme ve 5) ailelerle iletişim temalarını içermektedir. Bu temalara ilişkin bulgular ana hatları ile Tablo 2'de özetlenmiştir. .

Tablo 2. Proje yaklaşımının uygulamalara kısmi yansımaları

\begin{tabular}{|c|c|}
\hline $\begin{array}{r}\text { Proje Yaklaşımı Öncesi } \\
\end{array}$ & Proje Yaklaşımı Sonrası \\
\hline \multicolumn{2}{|l|}{ Genel Yaklaşım } \\
\hline Yaz aylarında daha serbest bir eğitim & Yaz aylarında daha verimli bir eğitim \\
\hline Hazır planların seçiminde belirsizlik & Hazır planların seçiminde titizlik \\
\hline $\begin{array}{l}\text { Çocuklara sık sık şeker ve çikolata verilmesi } \\
\text { Sınıf öğretmenleri arasında doğaçlama yapılan } \\
\text { işbölümü ve bir öğretmenin sınıfta daha etkin olması }\end{array}$ & $\begin{array}{l}\text { Şeker ve çikolata sayısının azaltılması } \\
\text { Öğretmenlerin sınıfta dönüşümlü sorumluluk alarak } \\
\text { etkin olması }\end{array}$ \\
\hline \multicolumn{2}{|l|}{ Etkinlikler } \\
\hline $\begin{array}{l}\text { Yarım günlük planlar ve rutinlere vurgu } \\
\text { Büyük grup ve bireysel etkinlikler } \\
\text { Etkinliklerde hazır malzeme kullanımı } \\
\text { Sohbet ağırlıklı Türkçe etkinlikleri } \\
\text { Alan gezileri için yetersiz ön hazırlık } \\
\text { Yapılandırılmış etkinlikler }\end{array}$ & $\begin{array}{l}\text { Tam günlük planlar ve etkinlik sayısının artırılması } \\
\text { Etkinliklerde küçük grup çalışmalarına yer verilmesi } \\
\text { Doğal, açık-uçlu ve artık materyallerle yaratıcı etkinlikler } \\
\text { Çocuklarla okunan kitap sayısının artması } \\
\text { Çocuklarla hazırlık ve değerlendirme } \\
\text { Yarı yapılandırılmış ve yapılandırılmamış etkinlikler }\end{array}$ \\
\hline \multicolumn{2}{|l|}{ Ortam ve Materyal Kullanımı } \\
\hline $\begin{array}{l}\text { Yeni öğrenilen sözcüklerin vurgulanmaması } \\
\text { İnternet erişiminin kısıtlılığı } \\
\text { Oyun zamanında evcilik materyalleri ve blokların } \\
\text { daha sık kullanılması }\end{array}$ & $\begin{array}{l}\text { Yeni öğrenilen sözcükler için görsel kartlar hazırlanması } \\
\text { Eğitimde teknoloji kullanımının artması } \\
\text { Öğrenme merkezi kullanım çizelgelerinin tutulması, } \\
\text { merkezlere isim verilmesi ve dönüşümlü kullanımın } \\
\text { sağlanması; oyun zamanında kitaplarla da etkileşimin } \\
\text { sağlaması }\end{array}$ \\
\hline $\begin{array}{l}\text { Sınıf duvarlarının yetişkin gözüne hitap etmesi } \\
\text { Açık hava etkinliklerin azlığ ve sadece oyun } \\
\text { bahçesinin kullanılması }\end{array}$ & $\begin{array}{l}\text { Sinıf duvarlarının eğitsel amaçlı ve işlevsel kullanılması } \\
\text { Açık hava etkinliklerinin artırılması ve oyun bahçesi } \\
\text { dışındaki yerlerden faydalanma }\end{array}$ \\
\hline \multicolumn{2}{|l|}{ Değerlendirme } \\
\hline $\begin{array}{l}\text { Sanat çalışmalarına sadece isim yazılması } \\
\text { Oyun zamanında evrak işleri \& sohbet } \\
\text { Çocukların ürünlerinin dosyalarda toplanması }\end{array}$ & $\begin{array}{l}\text { Çocukların düşüncelerini dinleme ve ürünlere yansıtma } \\
\text { Çocukların daha sistematik gözlenmesi } \\
\text { Etkinliklerde fotoğraf çekilmesi }\end{array}$ \\
\hline \multicolumn{2}{|l|}{ Ailelerle İletişim } \\
\hline $\begin{array}{l}\text { Eve gönderilen çalışmaların dönem ortasında } \\
\text { sonlanması } \\
\text { Ailelerle dönemlik toplantılar yapılması }\end{array}$ & $\begin{array}{l}\text { Çocukların evde yapabileceği etkinliklerin düzenli } \\
\text { olarak gönderilmesi } \\
\text { Ailelerle bireysel toplantılar ve telefon görüşmeleri } \\
\text { yapılması }\end{array}$ \\
\hline
\end{tabular}

Tablo 2'de görüldüğü gibi proje yaklaşımı sonrasında öğretmenler okulda eskiye oranla daha nitelikli çalışmalar yapmaya başlamışlardır. Çocukların meraklarını ve yaratıcılıklarını teşvik etme konusunda 
farkındalıklarının arttığını ve uygulamada kendi eksiklerini gördüklerini ifade etmişlerdir. $\mathrm{Bu}$ doğrultuda, öğretmenlerin genel yaklaşımı bu farkındalığa dair ipuçları içermiştir. Örneğin, yaz dönemini daha verimli geçirebileceklerini görmüşler ve sınıf içindeki işbölümünde dönüşümlü sorumluluk almaya başlamışlardır. Yine de öğretmenler planlama konusundaki tutumlarını sürdürmüşlerdir. Günlük planlamayı sadece üniversite yıllarında yaptıklarını, mesleğe başladıklarında ise "herkes gibi" hazır planlar uyguladıklarını belirtmişlerdir. Öğretmenler hazır planları kullanmaya devam etseler de planların açık uçlu, yaratıcı etkinlikler ve açık hava oyunları içermesine dikkat etmeye başlamışlardır.

Okulda yapılan gözlemler ve görüşmeler öğretmenlerin en fazla, etkinlikler ve ortam ve materyal kullanımı kapsamında değişimlere gittiğine işaret etmektedir. Tam günlük eğitim sürecinde az sayıda etkinliğe yer veren öğretmenler, hem etkinlik sayısında hem de türlerinde değişiklikler yapmışlardır. Örneğin, bazı okul çalışanları etkinliklerle ilgili olarak şu ifadeleri kullanmışlardır:

Fotoğrafların gösterilmesi ya da gezilerde işte gezi öncesi sohbetler, gezi sonrası yapılacaklar hani oralarda baya bir eksiklerimiz varmış açıkçası (... $)^{1}$ Hani bu tür şeyleri söylemek gerçekten çocukların da ilgisini çekiyor. Öncesinde sorular hazırlanması hani baya öğrendiğimiz şeyler de oldu açıkçası, bizim için faydaları da oldu (E3.G3).

"Uykuya daha az vakit harciyorlar, etkinliğe çok vakit harciyorlar. Önceden sadece sabahtan geliyorlardı, sadece oyun, yemek vaktini 11:30'a kadar oyunla harciyorlardı. Oyuncakları toplama derken yemeğe gidiyorlardı. Pek etkinlik yoktu o vakitte. Şimdi etkinlik var, bazı yerlerde etkinlik var” (DP3.G1).

Ortam ve materyal kullanımına yönelik olarak da bir çalışan gözlemlerini şöyle paylaşmıştır:

Çok çok etkili oldu. Mesela en küçük bir şey çocukları ara sıra da olsa çok kısa vakit de çıkartıyorlar, bitkileri inceliyorlar, işte ağaçları inceliyorlar, ne bileyim çocuklara bir değişiklik oluyor, oyun saatleri çok farklı, birtakım materyalleri kendileri edinmeye çalışıyorlar. Yani bu konularda baya baya ilerleme var yani (DP1. G2).

Değerlendirme teması kapsamında öğretmenler için en önemli kazanımın çocukları dinlemek olduğu gözlenmiştir. Bu konuda bir öğretmen, değişen tutumunu şöyle ifade etmiştir:

Yani güzel uygulamalar gerçekleştirdik. Olumlu yönlerinden, çocukları daha aktif, daha söz hakkı vererek, yani biz düz direkt anlatarak değil de onların görüşlerini çok fazla alarak, bilmediklerini düşünerek değil de onun hakkında ne düşündüklerini önce öğrendik. Mesela doğru mu biliyorlar, yanlış mı biliyorlar ona göre bir yol izleyebildik (E1.G3).

Sınıf öğretmenlerinin yıllık sergilerinde gözlenen farklar da proje yaklaşımı ile gelen çeşitli değişimlere işaret etmektedir. Proje başlamadan önce yapılan yıllık sergide kesme-yapıştırma ve

\footnotetext{
${ }^{1}$ (...) simgesi konuşmadan ilgisiz kısımların veya tekrarların çıkarıldığını göstermektedir. 
boyama ağırlıklı etkinlikler varken izleme döneminde ve sonrasında daha açık uçlu, yaratıcı ve çocukların düşüncelerini yansıtan etkinlikler yapıldığ1 görülmüştür (Şekil 1-3).

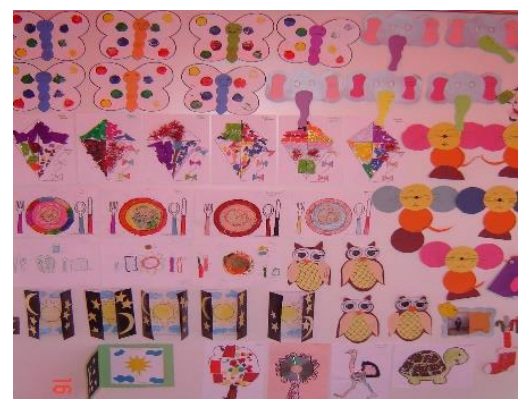

Şekil 1. 2014 Haziran Sergisi
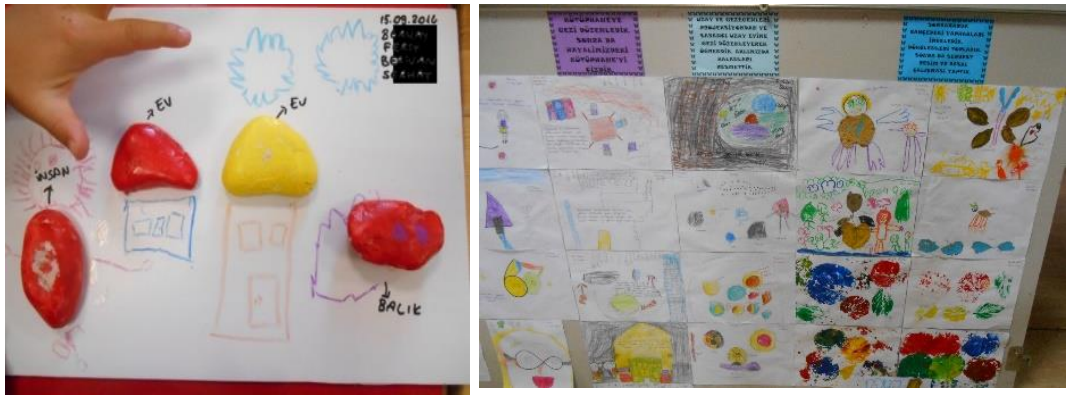

Şekil 2. Doğal Materyallerin Şekil 3. 2015 Haziran Sergisi Kullanımı

Proje uygulamaları sonrasında öğretmenlerin ailelerle iletişiminin artması da değişim gözlenen bir alandır. Araştırma sürecinin başında eğitimciler, aile katılımının düşük olduğunu belirterek, “ilgisizlik, çalışma, evde küçük çocukların olması ve diğer ailevi sorunları” bu duruma gerekçe olarak göstermişlerdir. Proje uygulamaları sırasında ise çaba harcandığında ailelere ulaşılabildiğine şahit olmuşlardır. Proje sürecinde araştırmacı, ailelerle düzenli iletişim kurmuş, çocukların ailelerle etkileşimini artıracak etkinlik örneklerini eve göndermiştir. Aileler de mümkün olduğunca bu çalışmalara cevap vermiş, sergiye neredeyse tüm aileler katılmış ve ailelerin bu çabaları çocukları da sınıfta daha istekli hale getirmiştir. Proje sürecinde öğretmenler ailelere yönelik olumlu sonuçları olduğuna şahit oldukları bu uygulamaları örnek alarak sonraki dönemde ailelerle iletişimlerini artırmışlardır. Okul sekreterinin ifadeleri de bu bulguları desteklemektedir:

\footnotetext{
Projeden önce anca sergi zamanı bir ürün oluşturup, bir kere herhalde onu da yanlış hatırlamıyorsam sergi için sadece, öyle bir şey istenmişti. Onun haricinde pek eve biz ödev göndermiyorduk ailelere, pek bir şey istemiyorduk. Yani projeyle birlikte daha fazla iletişime geçildi o yönde (...) Küçük sınıfın öğretmenleri mesela senenin başında hemen velileri tek tek aradılar, ilk hafta bilgi verdiler falan böyle. Onlar bence güzel şeylerdi (...) daha önce yoktu. Çoğu zaman bana arattırırlardı oradayken sen ara söyleyiver diye. Ama daha iyi, yani şu an daha iyi (G3).
}

Okulun akademik kurul toplantısında da ailelerle bireysel görüşmeler yapmaya ve aileleri okuldaki çalışmalara dâhil etmek için daha sistemli çalışmaya yönelik karar alınmıştır. Bu kapsamda bireysel görüşmeler planlanmış ve aileler okula davet edilmişlerdir (Şekil 4).

\footnotetext{
Sayın Veli;

Yukarıda yazılı olan tarihlerde sizleri saat 11:00'de okulumuza yarım saat çocuğunuzla ilgili bireysel görüşmeye ardından da yarım saat sınıfta herhangi bir etkinliğe (kitap okuma, deney yapma, fasulye cimlendirme, oyun oynatımı, çocuklarla birlikte resim yapımı vb.) katılmanızı rica ediyoruz. Lütfen adınızın karşısında yazılı olan tarihte ve saatte mutlaka okulda bulununuz. Katılımınız hem çocuğunuzu hem de bizi çok mutlu edecektir.
}

Șekil 4. Ailelere Gönderilen Davet 
Gözlemler ve diğer kurum belgeleri de öğretmenlerin ailelerle artan iletişimine işaret etmiştir. Öğretmenlerin ailelere haftalık bültenler, etkinlik örnekleri ve çeşitli konularda bilgilendirme yazıları gönderdikleri de gözlenmiştir (Şekil 5). Aşağıdaki ekran görüntüsü, Kelebekler adlı sınıftan ailelere gönderilen bültenlerin listesini göstermektedir. Diğer sınıf da benzer çalışmalar gerçekleştirmiştir.

\begin{tabular}{llll} 
Add & Değiştirme tarihi & Tür & Boyut \\
kelebekler bülten1 & $10.10 .201412: 00$ & Microsoft Word Belgesi & $16 \mathrm{~KB}$ \\
kelebekler bülten2 & $17.10 .201416: 14$ & Microsoft Word Belgesi & $16 \mathrm{~KB}$ \\
kelebekler bülten3 & $24.10 .201415: 52$ & Microsoft Word Belgesi & $16 \mathrm{~KB}$ \\
kelebekler bülten4 & $31.10 .201413: 29$ & Microsoft Word Belgesi & $16 \mathrm{~KB}$ \\
kelebekler boulten5 & $7.11 .201414: 39$ & Microsoft Word Belgesi & $17 \mathrm{~KB}$ \\
kelebekler bülten6 & $14.11 .201411: 38$ & Microsoft Word Belgesi & $17 \mathrm{~KB}$ \\
\hline
\end{tabular}

Şekil 5. Büyük Yaş Grubu Aile Katılımı Klasörü İçeriği

Şekil 5’teki dosyaların değiştirilme tarihleri de bu çalışmaların düzenli yapıldığını göstermektedir. Sonuç olarak proje uygulamaları, öğretmenleri daha sonraki dönemlerde ailelerle iletişime geçme konusunda güdülemiștir.

Proje Yaklaşımının Zorlukları. Katılımcı öğretmenler görüşmelerde proje yaklaşımının zorluklarını da vurgulamışlardır. Sınıf öğretmenlerinin tamamı, proje uygulamalarının araştırma ve planlama için ek zaman gerektirmesi ve iş yükü getirmesi, tek konuya odaklanılması, çocuk sayısının fazlalı̆̆1, yaş grubuna ilişkin zorluklar ve hazır planlarla proje uygulamalarını bütünleştirme konusundaki zorluklarına işaret etmişlerdir. Bu zorlukları özellikle tam gün çalıştıklarını vurgulayarak açıklamışlardır. Aşağıdaki alıntı öğretmenlerin bu düşüncelerini örneklendirmektedir:

\footnotetext{
Hani çok araştırma, inceleme gerektiren bir şey. Açıkçası hani sınıftan çok fazla giriş-çıkış yapamıyoruz ya da vaktimiz pek olmuyor diye düşünüyorum (...). Hani açıkçası bunları tam olarak yapabilir miyiz, pek yapamayız gibi geliyor. Bir de mesela bu sene ben küçük yaş alacağım için küçük yaşta çok daha zor olacak sınıfı boş bırakmak falan, dışarı çıkmak, tek bir öğretmenin başına birakmak daha zor olacak gibi geliyor (E3.G3).
}

Öğretmenlerin özellikle dönem içinde projeyi uygulamaya yönelik tereddütleri olduğu görülmüştür. Sadece yaz aylarında proje uygulayabileceklerini bildirmişler ve bu yönde toplu karar almıslardır:

Uygulamayı hani çalışacağız ama yaz tatillerinde, öğretmenler arasında konuşmuştuk yaz tatillerinde çok daha uygun olacağını, yazın aktif bir şekilde geçebileceğini düşündük. Zaten 1. ve 2. dönem boyunca da planlarımızı, günlük planlarımızı yine uygularız. Yazın bizim burada boş geçiyor, biraz daha hani serbest geçiyordu. Böyle bir etkinlik yaparsak eğer daha dolu dolu, daha olumlu geçeceğini, aktif geçeceğini düşünüyoruz (E2.G3). 
Gelecekte yani önümüzdeki dönem proje yaklaşımını komple bir bütün olarak değil de, içinden uyguladığımız şeylerden tabii ki bize faydalı olan şeyleri hep bizim eğitim akışlarımıza getirerek uygulamayı düşünüyoruz (E1.G3).

Bu karara istinaden 2015 Yaz döneminde öğretmenler sınıflarında Su ve Toprak konulu iki projeyi uygulamışlar ve çalışmalarını bilimsel bir ortamda paylaşmışlardır. Bu konferans deneyimi de öğretmenlerin mesleki gelişimine yönelik önemli bir bulgu olarak değerlendirilebilir. Sonuç olarak, sınıfta model olunduğunda öğretmenlerin uygulamalarını geliştirebilecekleri görülmüştür. Sınıf öğretmenleri proje uygulamaları sonrasında pratik ve teknik anlamda mikro düzeyde değişikliklere gitmişlerdir. Ancak, proje yaklaşımını dönem içinde bütün olarak uygulamak yerine hazır plan kullanmadıkları, daha az çocuğun okula devam ettiği ve öğretmenlerin ifadesi ile 'boş geçen’ yaz döneminde uygulamayı yapılabilir bulmuşlardır.

\section{Çocukların Deneyimleri: 'Bomboş gelen çocuklar o kadar da dezavantajlı değillermiş!'}

Proje yaklaşımının uygulanması ile çocuklarda gerek etkinliklere katılıma yönelik tutumlar gerekse öğrenme açısından olumlu deneyimler gözlenmiş olup bu bulgular okul çalışanları ve ailelerin görüşleri ile de desteklenmiştir. Dezavantajlı çocukların proje yaklaşımı konusundaki deneyimleri, 1) beklentileri aşma, 2) sosyal-duygusal kazanmlar, 3) bilissel kazanmmlar ve 3) dil alanmda kazanmlar temalarını içermektedir.

Beklentileri Aşma. Çocuklar proje etkinliklerine gösterdikleri ilgi ve yapabildikleri ile sınıf öğretmenlerini şaşırtarak öğretmenlerin beklentilerini aşmışlardır. Araştırmanın başlangıcında öğretmenler, çocukların akademik potansiyellerinin düşüklüğü nedeniyle okulda yapılan çalışmaların yorucu olduğunu ifade etmişlerdir. Bir taraftan çocukların eksik uyaran ortamından gelmelerinin çocuklar için yarattı̆̆ı olumsuzluk vurgulanırken, diğer taraftan yapılacak çalışmaların etkileri konusunda karamsarlık dile getirilmiştir. Bu ifadeler sınıf öğretmenlerinin kurumdaki çocuklardan düşük beklentileri olduğuna işaret etmektedir. Çocukların grup çalışmalarında işbirliği yapamayacaklarını söylemişler hatta sınıfta bir öğrencinin örnek olarak uyguladığı bir küçük-grup etkinliğinde çocuklar dağılınca müdahale etmeden gülerek izlemişlerdir (Gözlem, 28.05.2014). Sınıf öğretmenleri, bazı istisnalar haricinde genel olarak okuldaki çocukların ilgisizliğini, dikkatlerinin çabuk dağıldığını ve yaratıcı olmadıklarını dile getirmişler; okula başlarken "bomboş" geldiklerini belirtmişlerdir. Örneğin, bir öğretmen oyun zamanında çocukların tüm yaptıklarının "ya evcilik ya da arabalarla oynamak" olduğunu; "Legoları bile evciliğe dönüştürerek" sadece aile ortamlarındaki ilişkileri oyunlarına yansıttıklarını ifade etmiştir:

Yani sadece evlilik birbirleriyle arkadaşlık, gelme, gitme karı koca olma, doğum yapma, kızlar genelde bebekleri karınlarına koyuyorlar, doğum yapıyorlar. Bu şekilde. Hatta geçen yıl bir öğrencim 
vardı dokuz kardeşlerdi, kız oyunlarda sürekli ama sürekli hamile, annesi sürekli doğum yaptığı için uyaran çevreleri o şekilde olduğu için (E3).

Başka bir öğretmen de çocukların durumunu, "Uyaranları aç, evde şimdiye kadar hiçbir şekilde uyaran verilmemiş gibi geliyor bize. Çünkü gerçekten dikkatlerini çekmekte de zorlanıyoruz bazen. Bazen isimlerine bile tepki vermiyorlar, ismini söylediğimiz zaman bile tepkisiz kalabiliyorlar (E1.G2)" şeklinde tanımlamıştır. Proje öncesindeki bu tanımlamalar, mevcut aile ortamında çocukların eğitimle başarabilecekleri konusunda öğretmenlerin karamsar olduklarını göstermektedir. Nitekim ‘Çocuğunuzu bu okula göndermek ister miydiniz?’ şeklinde yöneltilen bir soruya bir kişi hariç tüm eğitimciler kendi çocuklarının gerileyeceğini belirterek olumsuz yanıt vermişlerdir. Okuldaki gözlemler ve grup toplantılarındaki değerlendirmeler de bu bulguyu desteklemektedir. Bir eğitim toplantısının ardından araştırmacı, günlüğ̈nde şunları yazmıştır:

"Eğitim sırasında videolar göstermem, sınıftan örnekler vermem, çocukların davranışlarından örnekler vermem etkili oldu. Göz kontağı küçük sınıfın öğretmeni ile sınırlı olsa da diğerleri dikkatle dinlediler yorumlar yaptılar. Ancak verdiğim öneriler konusunda 'ama bizim çocuklar' şeklinde başlayan cümleler kurmaya devam ettiler” (Araştırmacı Günlüğü, 21.05.2014).

Benzer bir toplantıda sınıf öğretmenleri çocukların meraksız ve ilgisiz olduğunu şöyle paylaşmıştır:

"Çok fazla bir şeye heyecanlanmıyorlar açıkçası. Onların merak edip de geldikleri bir konuyu düşünüyorum, yok...Hani biz sunarsak ancak şey oluyor...Biz, bir şeyler sunduğumuzda farklı farklı sorular yönelttiğimizde merak ediyorlar(....)Ama ondan da çabuk sikıliyorlar..... Genişlemiyorlar konularda yani biz genişletirsek genişliyorlar. Merakları yok” (Grup Toplantısı, 04.07.2014).

Büyük yaş grubunda ücretli öğretmenin ağaçlar, küçük yaş grubunda da sınıf öğretmenlerinin ev hayvanları konulu projeleri uygulamalarından sonra ise öğretmenlerin düşüncelerinde değişme gözlenmiş, 'beni şaşırtan çocuklar oldu açıkçası' gibi ifadeler kullanmışlardır. Örneğin, bir eğitimcinin "İşte yeterlilikleri açısından yetmediğini, onların aşağıda olduğunu düşünüyorduk ama aslında içlerinde varmış (E5.G3)" cümleleri bu değişime işaret etmektedir. Bu konuda başka bir öğretmen de şunları söylemiştir:

Bir şeyin resmini yapamazlar falan demiştim ben ilk başta bu yaprak konusunda falan. Çok güzel de bakarak resimlerini yapabildiler, ürünlerini oluşturabildiler. Yani bence de çok da dezavantajlı da değiller diye düşünüyorum ben. Belki imkânlar daha fazla olsa çok daha fazla şeyler yapabilirler (...) Çok şaşırtan çocuklar oldu beni içlerinde, yani hiç beklemediğim çocuklardan çok güzel performanslar çıktı. Yaz dönemine denk geldi, hani bazıları gerçekten devamsızlık yaptı, hiç dikkatini bile çekmedi, hani hiç uğraşmadı. Ama çok çocukların da hani bu konuyla ilgili böyle fikirler yürüttüklerini, onların ilgisini çektiğini de gördüm açıçası. Açıç̧ası çocuklar kendilerini gösterdiler bence (E3.G4). 
Proje uygulamaları sırasında çocukların proje yaklaşımı ile öğrenmeye aslında hazır oldukları görülmüş̧tür. Çocuklar proje uygulamaları sırasında araştırmaya, yapılan etkinliklere ve kullanılan gerçek materyallere ilgi göstermişler ve bu ilgileri de süreç boyunca devam etmiştir. Zaman zaman ilginin dağgldığı gözlense de bu durumun ücretli öğretmenin zaman zaman uzun cümleler kurmas1, rutinler ve sınıfa diğer yetişkinlerin yemek veya temizlik için sık giriş-çıkış yapması ile ilgili olduğu gözlenmiştir. $\mathrm{Bu}$ bağlamda, proje yaklaşımı ile etkinliklere ilgi ile katılım gösteren dezavantajlı çocukların, öğretmenlerin beklentilerini aşması çocukların deneyimleri açısından birinci derecede önemli kazanımdır.

Sosyal-Duygusal Kazanımlar. Proje uygulamaları sırasında çocuklar, daha önce yaptıklarından farklı olarak her gün yeni uyaranlarla karşılaşmışlar ve geçmişe oranla daha yoğun bir günlük eğitim akışı deneyimlemişlerdir. Çocukların sosyal-duygusal alanda desteklenmesi gerektiği öğretmenler tarafindan da belirtildiği için bu konuda kitaplar da seçilerek Türkçe etkinliklerinde sosyal-duygusal kazanımlara yer verilmiştir. Serbest oyun zamanı için merkez kullanım çizelgeleri hazırlanmış, sınıf kuralları konusunda güne başlangıç zamanında görsel hatırlatıcılara başvurulmuştur. Çocukların sokakta oynama alışkanlığı olması ve hareket ihtiyacına istinaden açık havada yapılan çeşitli etkinliklere de yer verilmiştir. Okula özellikle düzenli devam eden çocukların özgüven, karar verme ve bağımsız girişimde bulunma, sorumluluk alma, işbirliği yapma, doğaya karşı olumlu tutumlar alanlarında farklı kazanımları proje etkinlikleri sırasında gözlenmiştir.

Çocukların bağımsız girişimde bulunma ve sorumluluk almasına örnek olarak araştırmacının şu kaydı dikkat çekicidir: "Hindistan cevizinin tadına bakalım diye (bir kız çocuğu) arkadaşlarına Hindistan cevizli çikolata getirmiș. Aynı çocuk önceki gün getirmeyi unuttuğu, kullanılmış gazete parçalarını da bugün evden getirmiş” (Gözlem, 19.08.2014). Çocukların proje sürecinde gözlenen bu kazanımlarını evde de sergilediği ailelerle yapılan görüşmelerden anlaşılmaktadır. Büyük yaş sınıfından bir anne, çocuğu hakkında şu gözlemleri paylaşmıştır: "Şimdi ne bulsa hemen ben bunu okula götüreceğim, diyor. Zor hakkından geliyorum. Ağlıyor, resmen servise ağlaya ağlaya biniyor. Gören dövdü sanır. Ben, bunu okula götüreceğim, kozalağı götüreceğim, geri dikeceğim ağacın şeyi, çiçek götüreceğim dikeceğim, ben ağaç dikeceğim” (Anne28. G2). Benzer ifadeleri küçük yaş grubundaki çocuklardan birinin annesi de kullanmıştır: "Önceden hayvanlara baktığı zaman çocuk bir şey yapmiyordu. Ama şimdi gördüğü zaman soruyor hem öğrendiklerini abisine olsun, bana olsun aktarıyor ya da bilmek istediklerini soruyor" (Anne17.G2). Bu ifadelerden de anlaşılacağı üzere proje uygulamaları ile her iki sınıfta da çocukların canlılara yönelik meraklarının arttığı ve doğaya karşı olumlu tutumlar kazandıkları görülmektedir.

Bilişsel Kazanımlar. Proje uygulamaları ile çocukların bilişsel kazanımlar açısından da olumlu deneyimleri tespit edilmiştir. Bu kazanımlara örnek olarak ilişkilendirme, akıl yürütme, 
gözlem, algıladıklarını hatırlama, ıraksak düşünme, sürdürülebilir ilgi ve merak verilebilir. Bu kazanımlar çocukların proje kapsamında araştırılan sorulara verdikleri yanıtlarda da belirginleşmiştir. Başlangıçta sorulan sorulara kısa veya yanlış cevaplar veren çocuklar proje sonunda yapılan değerlendirmelerde daha detaylı ve doğru cevaplar vermişlerdir. Örneğin, ağaçların canlı olup olmadığı ve bunu nasıl anladığımız sorusuna çocuklardan biri "Büyüyen ağaçlar canlı, büyümeyen ağaçlar cansızdır” şeklinde cevap vermiştir. Diğerleri de benzer cevaplar vermiş olup proje sürecinde, ağaçların canlı olduğunu öğrenmişlerdir. Öğrenmenin işaretleri olarak çocukların proje sonunda sorulara verdiği doğru cevaplar verilebilir ${ }^{1}$. Bilişsel kazanımlar konusunda sınıf öğretmenlerinden bir tanesi de şunları söylemiştir: "Bunlar daha fazla araştırıp daha fazla mantıksal olarak hani biraz daha ileriye gittiler diyebilirim. Bilişsel olarak kendilerini geliştirdiler diyebilirim. Mantık yürütme, ak1l yürütme konusunda daha fazla etkilerinin olduğunu düşünüyorum” (E2.G3.). Proje uygulamaları ile çocukların ağaçlar hakkında öğrendiklerini hevesle tekrar edip çevrelerindeki ağaçları gözlemeye başladıkları ve yeni ağaç türleri öğrenme çabası geliştirdikleri gözlenmiştir. Büyük yaş grubuna devam eden çocuklardan birinin annesi de şunları söylemiştir:

\footnotetext{
"Bana anlattılar, sen okula gidince öğretmenlerin sana şunu yaptırdı mı anne? Sizde şu zamanda bu var mıydı? Valla bizim hiç böyle bir şeyler yoktu, bizim öğretmenimiz göstermedi, siz çok şanslısınız ben böyle anlatıyorum onlara şimdi. Sen bu ağacı tanıyor musun? Tanımıyorum. Sen bu ağacı gördün mü? Onlar, bana soruyor, ben bilmiyorum. Ben, şimdi söylüyorum kızım bu ne ağacı? Hurma ağacı diyor. Bu ne ağacı diyorum işte sayıyor. Anne şu çikolata ağacı diyor yok canım ben var mıymış diyorum bak var biz yapıştırdık diyor (Anne22.G2).
}

Çocukların farklı etkinlikler sırasında sergiledikleri odaklanma ve dikkat de sürdürülebilir ilgi ve merakın göstergeleri olarak değerlendirilmiştir. Ücretli öğretmen de gözlemlerini şöyle paylaşmıştır:

Benim hiç tanımadığım bu grup çocuklar, ben hiç daha önce dezavantajlı bir grupla çalışmadım.

(....) Ben hiç şahit olmadım ki çocuk bu etkinliği yapmayalım desin ya da ben bu etkinliği sevmedim

desin. Belki olmuştur da 1-2 kişi etkinlik hakkında düşünmüş olabilir ama genel anlamda yani o yapılan etkinliğe aslında hep bir ilgileri var (G1).

Şekil 6 ve 7’de görülen fotoğraflar da çocukların bu ilgilerini göstermektedir. Bu fotoğraflarda çocuklar çeşitli materyallerle oynamakta ve etkinliklere tamamen kendilerini vermiş görünmektedir.

\footnotetext{
${ }^{1}$ Çocukların diğer cevapları için “Okul Öncesi Eğitimde Proje Yaklaşımı: Ağaç Bilimcilerin Araştırmaları Projesi” adlı yayını inceleyebilirsiniz.

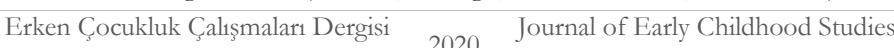




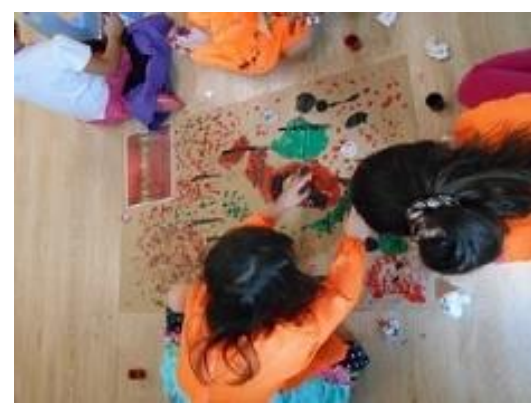

Şekil 6. Sanat Etkinliği

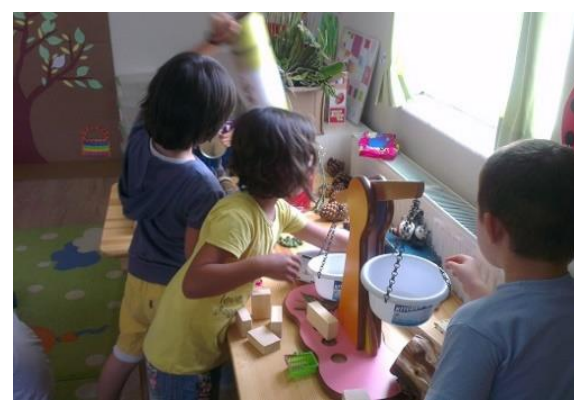

Şekil 7. Oyun Zamanı

Bu kazanımlar konusunda araştırmacı da günlüğüne şunları yazmıştır: “Alanya'da tatilde olan bir arkadaşımdan bize mart yemişi, zeytin ve muşmula ağaçlarının yapraklarını kargo ile göndermesini istedim. Çocuklar merak ettiler, ne zaman gelecek diye soruyorlar" (21.07.2014). Sonuç olarak proje çalışmaları sürecinde çocukların bilişsel kazanımları olduğu gözlenmiş ve farklı katılımcılarla yapılan görüşmeler de bu bulguları desteklemiştir.

Dil Alanında Kazanımlar. Proje uygulamaları ile çocukların dil alanındaki kazanımları da desteklenmiş ve soru sorma, cevap verme, dinleme, öğrendiklerini yeni sözcüklerle ve yaratıcı şekilde ifade etme gibi becerileri kullandıkları ve kelime hazinelerini arttırdıkları gözlenmiştir. $\mathrm{Bu}$ becerilerin gelişmesinde çocuklara fikirlerini sorma, çocukların kendilerini ifade edebilecekleri etkinliklerin sayısını artırma, küçük-grup çalısmaları, resimli sözcük kartları kullanma ve kitaplarla etkileşimi artırmanın etkili olduğu ifade edilebilir. Özellikle kitaplar konusunda dönem içinde yeterince uyaran sağlanmadığı gözlenmiş ve öğretmenler bu konuda çocukların ilgisiz olduğunu ifade etmişlerdir. Okulda hiç açılmamış kitap setleri olduğu gözlenmiş ve her uygulama gününde ve uyku saati öncesinde kitaplarla çocukların etkileşmesi sağlanmıştır. Bir destek personeli çocukların kitaplarla etkileşimine yönelik gözlemlerini şöyle ifade etmiştir: "Kitap etkinliği, önemli olan mesela kitap. Kitap alma alışkanlığını öğrendiler. Beklemek, okuma, bakma, inceleme şeyini öğrendiler” (DP3.G1).

Sınıf öğretmenleri de çocukların dil alanındaki çeşitli kazanımlarını vurgulamışlardır. "Kendilerine öncelikle daha güvenmeye başladılar, bir şeyleri ifade etmeye başladılar, yeni bir şeyler öğrendiler, kendileri de evde araştırdılar. Yani daha az konuşan çocuklarımızın daha çok konuşmaya başladığını gözlemledim” (E4.G3). Başka bir eğitimci de şöyle demiştir: “Çok güzel gelişmeler olduğunu, işte evde de her şeyi sorguladıklarını, soru sorduklarını ve yani yeni bir şeyler öğrenmek için evde de böyle çaba gösterdiklerini, önceki davranışlarından çok farklı davrandıklarını aileler de söyledi, anneler de söyledi” (E6. G3). Dil becerileri konusunda ücretli öğretmen de düşüncelerini şöyle açıklamıştır: 
Dil becerileri açısından mesela şöyle bir avantajı oldu bence, çocuklar biraz daha grup önünde bir şeylerden bahsedebilir hale gelmeye başladılar. Yani ne bileyim başkana mektup olsun ya da işte grup önünde ağaçları konuşturma olsun, işte ağaçları öğrenip işte bu budur, şudur, şunun şöyle özellikleri vardır hani birilerine hitap edebilmeyi biraz daha öğrenmiş hale geldiler bence. Çünkü ondan öncesinde böyle bir şey çok yaşadıklarını zannetmiyorum. Çünkü onların da şaşırdığı bir süreç oldu. O anlamda kullandıkları sözcükler arttı, ne bileyim bir süre sonra düzenli olarak bir şey anlatmaya başlayabildiler bence. Mesela en basitinden o ağaç şeyinde gördük onu, ikiye böldük, yarısını sen anlat, yarısını sen anlat dedik. Hani 2 cümleyi, 3 cümleyi birleştirerek bir şeyleri konuşur hale geldiler diye düşünüyorum. (G1).

Genel olarak her iki sınıf için geçerliliği gözlenen bu sonuçların okula düzenli devam eden çocuklar için daha belirgin olduğu ifade edilebilir. Zira çocuklarla yapılan görüşmelerde, sözcük kartları ile oluşturulan hikâyeler ve sorulara verilen cevaplar devamsızlık yapmayan çocuklarda daha fazla detay ve akıcılık içermiştir. Bu durum dezavantajlı koşullarda yaşayan çocuklar için okula düzenli devam etmenin proje kazanımları açısından önemine işaret etmektedir. Nitekim devamsızlı̆̆ı yüksek çocukların, "Ağaçlar olmasaydı ne olurdu?” sorusuna verdikleri cevaplar sınırlı sayıda sözcük ve telaffuz hataları içermiştir (G2):

KıZÇ18: Ağaçlar olmasaydı, dünya böyle böyle çirkin çirkin kalardı...

KızÇ19: Hatırlamıyorum.

ErkÇ24: Evler...ev

Sonuç olarak Mutlu Karıncalar Anaokulunda proje yaklaşımının uygulanması, çocuklar için etkin öğrenme ortamı yaratmış; özellikle okula düzenli devam eden çocukların farklı alanlarda kazanımlarını çok yönlü desteklemiştir.

\section{Ailelerin Deneyimleri: 'Önceden kalıplaşmış şeyler yapıyorlardı bu çok farklı'}

Proje uygulamalarının aileler için olumlu deneyimler kazandırdığı ve dezavantajlı ailelerle proje çalışmalarının yapılabilirliği görülmüştür. Proje boyunca ailelere, araştırmacı ve ücretli öğretmen tarafından düzenli bilgi verilmiş, çocukları ile yapabilecekleri araştırma ve etkinlik önerileri gönderilmiş, devamsızlık yapan çocuklarla konusunda telefon edilmiştir. Ailelerin proje yaklaşımı konusundaki deneyimleri 1) eğitsel farkindalık ve 2) çocukla etkileşimler temalarında değerlendirilen bulgular içermektedir.

Eğitsel Farkındalık. Ailelerin proje yaklaşımı ile eğitim konusunda farkındalığının arttı̆̆1 proje etkinliklerini değerlendirmelerinden anlaşılmaktadır. Proje yaklaşımı ile farklı uyaranlarla karşılaşan ve eve gönderilen çalışmalarda sorumluluk alan aileler okul öncesinde yapılan çalışmaların eğitsel yönünü fark etmişlerdir. Proje sergisinde pek çok ailenin çocuklarının yaptıkları ve öğrendikleri karşısında şaşırdığ1 ve duygusal anlar yaşadığı gözlenmiştir. "Gerçekten çocuklar mı yaptı bu çalışmaları?” "Ne kadar güzel!" "Keşke böyle çalışmalar hep devam etse” "Önceden daha 
kalıplaşmış şeyler yapıyorlardı, bu yaptıkları çok farklı" ifadeleri ile yapılan uygulamanın daha önceki çalışmalardan farkını vurgulamışlardır. Aşağıda, annelerin bu ifadelerinden örneklere yer verilmiştir:

Şimdi araştırma yapmayı öğrendikleri için şimdi hani bu biraz daha cazip geliyor daha güzel beyinlerine işliyor. Öbür türlü ezber olması biraz yani benim mesela hiçbir zaman ezberim kuvvetli değildir. Onun da öyle olabilir çünkü hani araştırarak bir şeyleri öğrenerek insanın aklında daha güzel kalır. Böyle olması daha güzeldir (Anne9.G2).

Orada da (2014 Mezuniyet sergisinde) aile ve çocuk katılımı vardı ama buradaki kadar fazla değildi, buradaki kadar bilinçli eğitim verici şekilde değildi açıkçası. Ailelerin desteği vardı ama çocukları bilgilendirdiğimizi düşünmüyorum ben. Hani daha böyle yüzeyseldi, bu daha bilimseldi. Daha çok şey kattığına inanıyorum çocuklara (Anne34.G2).

Son olarak bir babaannenin şu ifadesi eğitsel farkındalı̆̆a örnek verilebilir: "Çocuklar da bizler de eğitildik okulda. Bilgilendirildik, gözümüz açıldı. E şimdi, nasip olur da şu küçük de giderse, tamamen anlayacak oranın nasıl bir şey olduğunu" (Büyükanne32.G2). Ailelerin bu artan farkındalı̆̆ı evde çocukları ile yaptıkları çalışmalarda çaba göstermeleri ile de paralellik göstermektedir. Örneğin, “Sokağınızda kaç tane ağaç var çocuğunuzla birlikte mümkün olduğunca sayınız ve konuşunuz. Kâğıda not ederek okula geri gönderiniz” şeklinde okuldan gönderilen nota bir büyükanne 45 fidan şeklinde cevap göndermiştir. Her uygulama gününde büyük yaş sınıfinda 56 farklı çocuğun ailesi okuldan gönderilen bu tür çalışmalara cevap vermişlerdir. Eğitimcilerden biri aileler için şu ifadeleri kullanmıştır: “Aileler de demek ki benimsemişler. Siz de gittiniz tabi görüştünüz falan, o da çok etkili oldu bence. Ödevlere hep karşılık vermeye çalıştılar. Hani bazıları internetten falan bile gitmiş araştırmış, bulmuş. Büyük bir şey! (Gülüyor)" (E4.G4). Benzer şekilde kurumdaki eğitimcilerden birinin ifadeleri de bu bulguyu desteklemektedir:

Ailelere biz hep şikâyetimiz oydu zaten, hani bakıcı gibi görünüyor diye. Ailelerin katılımını pek fazla alamıyorduk. Ama şimdi proje uygulamasından bu yana ailelere de yazılar gidiyor ve cevaplar geliyor. Demek ki evet onlar üzerinde de olumlu bir etkisi var, çocuklarıyla ilgilendiklerini, bir şeyler paylaşmayı istediklerini gösteriyor. Onları da bir yönde dürtmüş olduk (E6.G4).

Ailelerin bu çabaları konusunda bazı öğretmenlerin yine de umutsuz olduğu ve ailelerin projeye katılımını yeterli bulmadığı görülmüştür. Bu konuda öğretmenlerden biri şu ifadeleri kullanmıştır:

Belki ailenin katılımı biraz daha şey olabilirdi, daha fazla olabilirdi bir araştırma, inceleme yönünde. Çünkü katılan çocuğumuz 5-6 tane bir şeydi diyebilirim hani o kadar çocuğun içerisinde. Diğerleri daha ilgisiz kaldı, belki onlar biraz daha ilgili olabilir ya da araştıranlar da sadece evdeki şeylerle kalmaz, biraz daha farklı şeyler öğrenmek isteyebilirler, merak edebilirlerdi. Biz sadece merak ettirdikçe bir şeyler yürüdü açıkçası (E3.G4).

Özellikle lise mezunları ve kendi sosyal çevresinden farklı yerlerde çalışan anneler bu taleplere daha sık cevap vermişlerdir. Örneğin, bir anne, "Kâğıtlar falan kullanılmış gazete falan varsa gönderin 
dediler, çok güzel bir şey. Ben de kızımı göndermemiştim, açık görüşe gittik çünkü arkadaşım aracıllğ̆1yla öğrendik onunla topladık, kâğıdı falan gönderdim” (Anne28.G2) diyerek kendi çabasını ifade etmiştir. Bu anne, babasını görmesi için çocuğunu cezaevine götürdüğü halde diğer ailelerden bilgi alarak okulun isteğini karşılamaya çalışmıştır. Tüm aileler her çalışmaya cevap vermese de ailelerin çocukla ev ortamında artan etkileşimleri eğitsel farkındalığın başka bir göstergesi olarak değerlendirilebilir.

Çocuklarla Etkileşim. Ailelerin proje uygulamaları sürecinde çocukları ile etkileşimleri artmış görünmektedir. Çocukla konuşma ve çocuktan öğrenme alt temaları bu bulguyu desteklemektedir. Bu konuda, ücretli öğretmen şu ifadeleri kullanmıştır:

Yani konuştu, konuşmak ki bence en önemlisi, büyük ihtimalle ne kadar konuşuyorlardır gün içinde bilmiyorum da en azından bir 15 dakika çocuk annesiyle, babasıyla, abisiyle, ablasıyla neyse artık bir şey paylaştı, bir şey konuştu. Bence aile katılımının bu grupla ilgili en önemli getirisi bu. Onun dişında zaten çok ekstra bir şey talep etmedik onlardan (G1).

Ailelerden de bu konuda alınan geri bildirimler ailelerin çocukları ile proje hakkında konuştukları ve bu sırada çocuklarından yeni şeyler öğrendiklerini göstermektedir. Bir annenin şu ifadesi bu bulguya örnek verilebilir: "Ben Hindistan cevizini çok seven bir insanım ama hangi ağaçta yetiştiğini bilmiyordum. Sizlerin, kızımın sayesinde öğrenmiş oldum palmiyeden yetiştiğini. Hatta kızım, 'Anne Hindistan cevizi palmiye ağacında yetişiyormuş' dedi. Olur mu kızım? Palmiye ağacında Hindistan cevizi ne ararmış falan demiştim” (Anne33.G2). Benzer şekilde başka bir anne şunları söylemiştir:

Bilgilerimi tazelediğimi hatta bilmediklerimi öğrendiğimi düşünüyorum. Sanki ben de kreşe gidiyor gibiyim o benim büyüğüm ben onun çocuğuyum ben ondan birçok şey öğrendim. (Gülüyor) Bana geldi Ejderha Kanı çok güzel bir ağaç, “yalan söylüyorsun” demedim tabii çocuğu yalana iter diye. Allah Allah ben hiç görmedim "hayalinde bir ağaç olmasın" dedim. "Hayır, anne var işte gördüm” dedi (Anne30.G2).

$\mathrm{Bu}$ ve benzeri ifadeler proje uygulamaları sürecinde ailelerin çocuklarla etkileşiminin sadece konuşma ve dinleme ile sınırlı kalmadığını ailelerin çocuklarından yeni şeyler öğrendiğini de göstermektedir.

\section{SONUÇ ve TARTIŞMA}

Bu araştırmada dezavantajlı çocuklar ve ailelerine hizmet veren bir anaokulunda farklı katılımcıların proje yaklaşımına yönelik deneyimleri çok yönlü olarak betimlenmiştir. Okul öncesi öğretmenlerinin, proje uygulamaları sürecinde öğrendikleri bazı eğitsel uygulamaları kısmen benimsedikleri ancak proje yaklaşımına yıl içinde bütün olarak başvurma konusunda dirençli 
oldukları gözlenmiştir. Öğretmenler, proje yaklaşımına dayalı çalışmalarını, hazır plan uygulamadıkları yaz dönemlerinde uygulamayı tercih etmektedirler. Proje yaklaşımı ile ilgili zorluklardan öne çıkanlar hazır planlarla proje yaklaşımını bütünleştirme endişesi, projenin ek zaman gerektirmesi ve fazla iş yükü getirmesi; dönem içinde okula devam eden çocuk sayısının fazla olmasıdır. Öğretmenler bu zorlukları açıklarken arada ikişer haftalık tatiller olsa da tam gün ve tüm yıl çalışmanın getirdiği olumsuzluğa vurgu yapmıştır. Diğer taraftan, okulda proje uygulama konusunda öğretmenlerin tutumlarını etkilediği öngörülen olumsuz bir okul iklimi de gözlenmiştir. Çocuklar proje uygulamaları ile öğretmenlerin beklentilerini aşmıss ve sosyal-duygusal, bilişsel ve dil alanında kazanımlar sergilemişlerdir. Tüm çocuklar proje boyunca yapılan çalışmalarda etkin olmuşlar ve ilgi ile çalışmalara katılmışlar ancak gelişimsel kazanımlar özellikle düzenli devam eden öğrencilerde belirginleşmiştir. Ailelerin ise eğitsel farkındalığ1 ve çocuklarla evde etkileşimi artmıştır. Aileler, proje uygulamalarının dönem içindeki çalışmalardan farklarını vurgulamışlar ve çocukları ile evde konuşarak onlardan öğrenme firsatları yakalamışlardır.

$\mathrm{Bu}$ araştırmada proje yaklaşımının dezavantajlılık bağlamında uygulanması ile ulaşılan bulgular alanyazındaki araştırmalar ve uygulamalı çalışmalara katkı sağlamaktadır. Proje yaklaşımının öğretmenlerin mesleki gelişimine yönelik katkılarına ve uygulamada karşılaşılan zorluklara farklı ülkelerde yapılan çalışmalarla dikkat çekilmiștir (Beneke ve Ostrosky, 2009; Rahman, Yasin ve Yassin; 2011; Yuen, 2009). Rahman, Yasin ve Yassin (2011) tarafindan Malezya'da yürütülen bir eylem araştırmasında, öğretmenlerin tutumları ve deneyimleri araştırılmıştır. Araştırmada, öğretmenlerin düşüncelerinin olumsuzdan olumluya doğru değisstiğine dikkat çekilmiş ve proje yaklaşımının mesleki gelişime katkısı vurgulanmıştır. Yuen (2009) de 'Ayaklardan Ayakkabılara' adlı proje uygulamasını değerlendirdiği çalısmada, aileler ve çocuklar arasında artan etkileşimlere ve öğretmen-aile ilişkilerinin olumlu niteliğine dikkat çekmiştir. Öğretmenlerinse mesleki kazanımlardan hoşnut olmakla birlikte proje uygulamalarının zaman alması, tüm çocukların eşit katılım göstermemesi ve kontrolü çocuklara bırakma konusunda yaşadıkları kaygıları vurgulamıştır. Hertzog (2009) da parlak ancak yoksul çocuklarla proje uygulamalarında karşılaşılan sorunları araştırmıştır. İlkokul öğretmenlerinin katıldığı bu çalışmada da benzer bulgulara ulaşılmıştır. Öğretmenler için çocukların özellikleri, mevcut eğitim programı ve okul ortamı gibi dış etkenler ve kendi inanç ve uygulamaları proje uygulamalarında önemli engeller olarak gözlenmiştir. Farklı ülkelerde, farklı eğitim kademeleri ve gruplarla yapılan çeșitli çalışmalara benzer sonuçlara bu araştırma kapsamında da ulaşılmış olması proje yaklaşımında öğretmenler için zaman kaybı ve iş yükünü azaltacak yönde değişimlerin güdülenmeyi artırabileceğine işaret etmektedir (Holm, 2011). Öğretmenlerin farklı proje konularında güvenilir bilgiye ve araştırma temelli etkinliklere ulaşabileceği çevrimiçi kaynaklar sunulması, alan gezileri için bürokratik işlemlerin kolaylaştırılması 
ve öğretmenlere eğitim planlaması için eğitim saatleri dışında zaman verilmesi bu yaklaşımı öğretmenlerin benimsemelerine yardımcı olabilir. Öğretmenler kendi alanlarında farklı yaklaşımları öğrenmeye açık olup, bu yaklaşımları hayata geçirmede okul iklimini de dikkate alarak öğretmenlere sınıf ortamlarında destek olmak önemli görülmektedir. Öğretmenlerin proje sürecinde gözledikleri bazı uygulamaları benimsemelerine dayalı olarak da hizmet içi eğitimde işbaşında yaklaşımlara başvurulması önerilebilir (Beneke ve Ostrosky, 2009).

Proje yaklaşımının dezavantajlı çocuklar açısından sonuçları değerlendirildiğinde çeşitli gelişimsel alanlarda kazanımların desteklendiği gözlenmiştir. Proje yaklaşımı özellikle okula düzenli devam eden çocuklarda bu kazanımları desteklese de tüm çocukların daha önce karşılaşmadıkları etkinliklere ilgi gösterdiği gözlenmiştir. Proje boyunca çocukların özgün ürünler ortaya koyabilecekleri etkinliklere, açık uçlu ve doğal materyallere, küçük-grup çalışmalarına ve açık havada öğrenmeye yer verilmesi ilgiyi canlı tutmuş ve çocuklarda sosyal-duygusal becerileri desteklemiş görünmektedir. Bu bulgular, özellikle sosyal-duygusal alana odaklı yapılmış sınırlı sayıdaki çalışmanın sonuçları ile paralellik göstermektedir (Beneke, 2010; Dresden ve Lee, 2007). Beneke (2010) tarafından özel gereksinimli çocuklarla gerçekleştirilen bir araştırmada, çocuklarda davranış sorunları ve sosyal etkileşim alanlarında proje yaklaşımının olumlu etkilerine dair bulgular mevcuttur. Benzer şekilde, Beneke ve Ostrosky (2009) de yaptıkları araştırmada çocukların artan katılım ve güdülenmelerine ve bu yaklaşımın çocuklar için olumlu akademik ve sosyal etkilerine dikkat çekmişlerdir.

Bu çalışmada tamamı dezavantajlı grupta olan çocukların bilişsel kazanımlarına yönelik bulgular genel sınıf ortamlarında yapılan güncel çalışmaların sonuçları ile benzerlik göstermektedir (Clucas, 2018; Kefi, 2017; Sawyer, 2013). Türkiye'de yapılan çeşitli çalışmalar da proje çalışmalarının gelişimsel etkilerini vurgulamaktadır. Bıçakçı ve Gürsoy’un (2010) 6-yaş grubu çocukları ile yaptıkları deneysel araştırmada, proje yaklaşımı ile eğitim alan grubun gelişimsel değerlendirme puanlarının diğer gruplardan daha yüksek olduğu bulunmuştur. Şahin, Güven ve Yurdatapan (2011) da okul öncesinde proje-tabanlı öğrenmenin çocukların bilimsel süreç becerilerini arttırdığını belirlemiştir. Proje yaklaşımının kavram gelişimine etkisinin incelendiği deneysel bir araştırmada da çocuklar açısından olumlu sonuçlar vurgulanmış ancak kavram gelişimi açısından anlamlı bir fark bulunamamıştır (Aral ve diğerleri, 2010). Aral ve diğerlerinin araştırmasında, proje 12 hafta sürmesine karşın proje uygulamalarına haftada bir gün yer verilmiştir. Kısa süreli veya uygulama sıklı̆ğ az olan proje uygulamalarında istenen etkiye ulaşılamayabilir. Bu çalışmada haftanın üç günü proje uygulamalarına yer verilmesinin çocukların kazanımlarında etkili olduğu söylenebilir. 
Araştırmada çocukların öğretmenlerinin beklentilerini aştığı önemli bulgular arasındadır. Proje uygulamaları ile yeterli çaba ve ilgi gösterildiğinde dezavantajlı koşullardan gelen çocukların da araştırma yapabildiği, sorular sorabildiği ve gözlemlerini aktarabildiği görülmüştür. Çocukların sözcük dağarcıkları artmış ve kendilerini ifade etme becerileri gelişmiştir. Ev ortamında yeterli uyaranla karşılaşmayan dezavantajlı çocukların proje yaklaşımı ile hem zihinsel hem de dil becerilerinin desteklenebileceği sonucu alanyazındaki bu araştırmalar ile paralel görünmektedir. Dresden ve Lee (2010) proje çalışmaları ile ilkokul çocuklarında kendini ifade etme becerilerinin arttı̆̆ı sonucuna ulaşmışlardır. Araştırmanın katılımcısı olan dezavantajlı çocukların eksik uyaran ortamlarından ve çoğunlukla parçalanmış ailelerden geldiği dikkate alındığında ise bu çocukların proje uygulamalarından edindikleri kazanımların aslında orta ve yüksek gelir grubundaki yaşıtlarına göre daha yüksek olduğu ifade edilebilir. Zira dezavantajlı çocukların kat ettikleri mesafe diğerlerinden daha fazladır. Çocukların daha fazla ipucuna ihtiyaç duyması ise bir engel veya zorluk değil, sosyokültürel kuram bağlamında yetişkin desteğinden faydalanabilecekleri bir firsat olarak değerlendirilebilir. Sınıf öğretmenlerinin sosyoekonomik açıdan dezavantajlı koşullarda yaşayan çocuklardan beklentilerinin yüksek olmasının ve evrensel eğitim anlayışı doğrultusunda zihinsel açıdan uyarıcı, ilgi çekici ve merak uyandırıcı çalışmalara eğitim sürecinde yer vermelerinin bu çocukların gelişimini bütüncül olarak destekleyeceği ifade edilebilir (Helm ve Lang, 2003). Bu bağlamda, proje yaklaşımının sunduğu bu çeşitlilikten ve gerçek yaşam deneyimlerinden uzun dönemli faydalanılması önemli görünmektedir. Ayrıca, dezavantajlı koşullarda yaşayan çocukların dil ve erken okuryazarlık becerilerini hem okulda hem de evde destekleyebilecek müdahalelerin etkili olacağı ifade edilebilir.

Proje uygulamalarının dezavantajlı aileler açısından da olumlu deneyimler kazandırdığı gözlenmiştir. Proje uygulamaları boyunca ailelerin çocukları ile etkileşimlerinin artması eğitim sürecini etkileyecek önemli bir bulgudur. Bu bulgular, ailelerde eğitsel farkındalı̆̆ın proje uygulamaları ile arttığını gösteren bazı çalışmalarla benzerlik taşımaktadır (Carida, 2011; Yuen; 2009). Ailelerin çocukları ile konuşma ve çocuklarından öğrenme şeklinde gözlenen etkileşimlerin de çocukların gelişimini destekleyeceği ifade edilebilir. Bazı öğretmenler proje sürecinde ailelerin katkılarını sınırlı görse de evde çocukla aile arasındaki etkileşimlerin okul yaşamına olumlu yansımaları olabilir. Dezavantajlı koşullarda yaşayan bu ailelerin genel özellikleri açısından eğitim düzeylerinin düşük olması, temel ihtiyaçları ve yaşadıkları sosyal çevre dikkate alındığında tüm ailelerin beklenen performansı gösteremeyeceği açıktır. Bu koşullarda, öğretmenlerin beklentilerine uygun olarak eğitimin evde devam ettirilmesi mümkün olmayabilir. Bu konuda alan yazın, ailelerle farklı düzeylerde kurulabilecek işbirliği ve iletişimin önemine dikkat çekmektedir (Epstein ve Sanders, 2006). Farklı 
koşullarda yaşayan ailelerle çalışma konusunda hizmet içi eğitimler okul öncesi öğretmenlerinin aileler hakkında daha kapsayıcı bakış açısı geliştirmelerine destek olabilir.

Sonuç olarak, bu araştırmanın bulguları bazı sınırlıklar 1şığında başka bağlamlara aktarılabilir. Bulguların değerlendirilmesinde araştırmanın yapıldığı kurumdaki öğretmenlerin tam gün ve tüm yıl olan çalışma takvimi ve olumsuz okul iklimi dikkate alınmalıdır (Arıkan, 2017b). Proje yaklaşımı ile okul öncesi öğretmenlerinin mesleki gelişimleri desteklenmiş olsa da eğitime yansıyan kısmi değişimin ve yaz aylarında proje uygulama kararının sonraki yıllarda sürdürülebilirliği mevcut koşullarda muğlak görünmektedir. Bu kapsamda dezavantajlı çocukların yarım gün eğitime devam ettiği ve tüm çalışanların ortak amaçlarda buluştuğu okullarda proje yaklaşımı konusunda yeni araştırmalar yapılabilir. Bu çalışmada katılımcı ögretmenlerin kadın olması ve uygulamanın kurum dışından bir öğretmenle uygulanması da önemli sınırlılıklardır. Gelecek araştırmalarda erkek öğretmenlere de ulaşılması ve sınıfında proje yaklaşımını uygulama konusunda kararlı öğretmenlerle katılımcı eylem araştırmaları yapılması önerilir.

\section{KAYNAKÇA}

Aral, N., Kandır, A., Ayhan, A. B., \& Yaşar, M. C. (2010). The influence of project-based curricula on six-year-old preschoolers' conceptual development. Social Behavior and Personality: An International Journal, 38(8), 1073-1079.

Arıkan, A., \& Kimzan, İ. (2016). Okul öncesi eğitimde proje yaklaşımı: Ăgaç bilimcilerin araştırmalar1 projesi [The project approach in preschool education: The inquiries of dendrologists project]. Elementary Education Online, 15(2), 498-528. doi: http://dx.doi.org/10.17051/io.2016.37190

Arıkan, A. (2017a, Kasım, 3-5). Okul öncesi eğitimde dezavantajh ailelerin deneyimleri: İlişkiler, etkileşimler ve beklentiler ekseninde aile katılım [Sözlü bildiri]. 1. International Symposium on Social Sciences and Educational Research, Antalya, Türkiye.

Arrkan, A. (2017b, Nisan, 27-29). Proje yaklaşımmda okul ikliminin önemi: Dezavantajl çocuklarla okul öncesi eğitimde proje uygulamalarna yönelike bir değerlendirme [Sözlü bildiri]. 7. International Congress of Research in Education, Çanakkale, Türkiye.

Beneke, S. J. (2010). The effects of the project approach on children in inclusive early childhood classrooms. (Yayınlanmamış Doktora Tezi). University of Illinois at Urbana-Champaign. Urbana, IL.

Beneke, S., \& Ostrosky, M. M. (2009). Teachers' views of the efficacy of incorporating the project approach into classroom practice with diverse learners. Early Childhood Research \& Practice, 11(1). https://eric.ed.gov/?id=EJ848843 adresinden 20 Mart 2014 tarihinde erişilmiştir.

Bıçakçı, M., \& Gürsoy, F. (2010). Proje yaklaşımına dayalı eğitimin altı yaş çocuklarının gelişimine etkisinin incelenmesi. Kastamonu Ë̆itim Dergisi, 18(1), 307-316. 
Borre, A. J., Bernhard, J., Bleiker, C., \& Winsler, A. (2019). Preschool literacy intervention for lowincome, ethnically diverse children: Effects of the early authors program through kindergarten. Journal of Education for Students Placed at Risk, 24(2), 132-153. doi: https://doi.org/10.1080/10824669.2019.1594818

Brooks, M., \& Wangmo, T. (2011). Introducing the project Approach and use of visual representation to early childhood education in Bhutan. Early Childhood Research \& Practice, 13(1). http://ecrp.uiuc.edu/v13n1/brooks.html adresinden 30 Ağustos 2014 tarihinde erişilmiştir.

Carida, H. C. (2011). Planning and implementing an educational programme for the smooth transition from kindergarten to primary school: The Greek project in all-day kindergartens. The Curriculum Journal, 22(1), 77-92.

Chang, M., Park, B., Singh, K., \& Sung, Y. Y. (2009). Parental involvement, parenting behaviors, and children's cognitive development in low-income and minority families. Journal of Research in Childhood Education, 23(3), 309-324.

Clucas, M. (2018). Science learning opportunities and the project approach in preschool classrooms. (Yayınlanmamış Doktora Tezi). Iowa State University. Ames, IA

Corbin, J., \& Strauss, A. (2008). Basics of qualitative research. Los Angeles: Sage Publications.

Creswell, J. W. (2007). Qualitative inquiry \& research design: choosing among five approaches. Thousand Oaks: Sage Publications.

Crosnoe, R., \& Cooper, C. E. (2010). Economically disadvantaged children's transitions into elementary school: Linking family processes, school contexts, and educational policy. American Educational Research Journal, 47(2), 258-291. https://doi.org/10.3102/0002831209351564

Crosnoe, R., Leventhal, T., Wirth, R. J., Pierce, K. M., \& Pianta, R. C. (2010). Family socioeconomic status and consistent environmental stimulation in early childhood. Child Development, 81(3), 972-987. https://doi.org/10.1111/j.1467-8624.2010.01446.x

Cuthrell, K., Stapleton, J., \& Ledford, C. (2009). Examining the culture of poverty: Promising practices. Preventing School Failure, 54(2), 104-110.

Çabuk, B., \& Haktanır, G. (2010). What should be learned in kindergarten? A Project approach example. Procedia-Social and Behavioral Sciences, 2(2), 2550-2555.

Dahlberg, G., \& Moss, P. (2010). Introduction: Our Reggio Emilia (p.1-22). In C, Rinaldi. (Ed.), In dialogue with Reggio Emilia: Listening, researching and learning. NY: Routledge, Taylor \& Francis Group.

Dearing, E., McCartney, K., \& Taylor, B. A. (2009). Does higher quality early childcare promote low-income children's math and reading achievement in middle childhood? Child Development, 80(5), 1329-1349. https://doi.org/10.1111/j.1467-8624.2009.01336.x

Dresden, J., \& Lee, K. (2007). The effects of project work in a first-grade classroom: a little goes a long way. Early Childhood Research \& Practice, 9(1). 
http://files.eric.ed.gov/fulltext/EJ1084751.pdf adresinden 25 Nisan 2015 tarihinde erişilmiştir.

Epstein, J. L., \& Sanders, M. G. (2006). Prospects for change: Preparing educators for school, family, and community partnerships. Peabody journal of Education, 81 (2), 81-120.

Friese, S. (2014). ATLAS.ti 7 User guide and reference (2nd ed). Washington DC: Sage.

Helm, J. H., \& Lang, J. (2003). Overcoming the ill effects of poverty. İcinde J. Helm \& S. Beneke (Ed) The power of projects: Meeting contemporary challenges in early childhood classrooms: Strategies and solutions (s. 19-33). NY and London: Teachers College Press.

Helm, J. H., \& Katz, L. G. (2001). Young investigators: The project approach in the early years. Williston, VT: Teachers College Press.

Hertzog, B. (2007). Transporting pedagogy: Implementing the project approach in two first-grade classrooms. Journal of Advanced Academics, 18(4), 530-564.

Holm, M. (2011). Project-based instruction: A Review of the literature on effectiveness in prekindergarten. River academic journal, 7(2), 1-13.

Hovey, K. A., \& Ferguson, S. L. (2014). Teacher perspectives and experiences: Using project-based learning with exceptional and diverse students. Curriculum and Teaching Dialogue, 16(1/2), 7799.

İnan, H. Z. (2012). Reggio Emilia Yaklaşımı ve proje yaklassımı. Ankara: Anı Yayıncılık.

Kabacık, S. Ç., \& Gül, E. D. (2016). Anasınıfına devam eden çocukların sebzelere ilişkin tepkilerinin incelenmesi: Proje yaklaşımı örneği. Kastamonu Education Journal, 24(5), 2323-2334.

Kandır, A., \& Kurt, F. (2010). Proje temelli okul öncesi eğitim programı. İstanbul: MORPA.

Katz, L., \& Chard, S. C. (2000). Engaging children's minds: The project approach (2nd ed.). Connecticut: Ablex Publishing Corporation, Stamford.

Kefi, S. (2017). Okul öncesi eğitimde proje yaklaşımı uygulamalarının temel bilimsel süreç becerilerini kapsama durumunun incelenmesi. Erken Çocukluk Çalısmalar Dergisi, 1(1), 3-18.

Mac Naughton, G., \& Hughes, P. (2009). Doing action research in early childhood studies: A Step-by-step guide. GB: Open University Press.

Merriam, S. B. (2009). Qualitative research: A guide to design and implementation. San Franscisco: Jossey-Bass.

Metin, Ş., \& Aral, N. (2014). Proje yaklaşımına dayah eğitim: Teoriden uygulamaya. Ankara: Vize.

Miles, M. B., Huberman, A. M., \& Saldaña, J. (2014). Qualitative data analysis: A Methods sourcebook. Thousand Oaks, Califorinia: Sage.

Miller, M. G. (2014). Productive and inclusive? How documentation concealed racialising practices in a diversity project. Early Years, 34(2), 146-160. 
Miller, S., Maguire, L. K., \& Macdonald, G. (2012). Home-based child development interventions for preschool children from socially disadvantaged families. Cochrane Database of Systematic Reviews, 7 (12). 1-71. DOI: https://doi.org/10.1002/14651858.CD008131.pub2

Oğuz, V., Gizir, Z., \& Akyol, A. K. (2014). Erken çocukluk eğitiminde proje yaklașımı ve uygulanmıs proje örnekleri. Ankara: Anı Yayıncilik.

Öztürk, Y. (2019). Okul öncesi eğitimde proje yaklaşımı. İçinde F.Z. Temel (Ed.) Erken çocukluk eğitiminde yaklasımlar ve programlar (s.405-443). Ankara: Vize Yayıncilık.

Rahman, S., Yasin, R. M., \& Yassin, S. F. M. (2011). The implementation of project-based approach at preschool education program. Procedia-Social and Behavioral Sciences, 18, 476-480.

Şahin, F., Güven, İ., \& Yurdatapan, M. (2011). Proje tabanlı eğitim uygulamalarının okul öncesi çocuklarında bilimsel süreç becerilerinin gelişimine etkisi. M.Ü. Atatürk. Eğitim Fakültesi Ë̈itim Bilimleri Dergisi, 33, 157-176.

Saldaña, J. (2015). The coding manual for qualitative researchers. Thousand Oaks, Califorinia: Sage.

Sawyer, G. L. (2013).The effects of traditional teaching methods, project-based learning, and a blended teaching style on elementary students. https://eric.ed.gov/?id=ED554195 adresinden 10 Ağustos 2016 tarihinde erişilmiştir.

Winsler, A., Tran, H., Hartman, S. C., Madigan, A. L., Manfra, L., \& Bleiker, C. (2008). School readiness gains made by ethnically diverse children in poverty attending center-based childcare and public school pre-kindergarten programs. Early Childhood Research Quarterly, 23(3), 314-329.

Yuen, L. H. F. (2009). From foot to shoes: Kindergartners', families' and teachers' perceptions of the project approach. Early Childhood Education Journal, 37(1), 23-33. 